
Association. This is an Open Access article, distributed under the terms of the Creative Commons Attribution-NonCommercial-NoDerivatives licence (http://creativecommons.org/licenses/by-nc-nd/4.0/), which permits non-commercial re-use, distribution, and reproduction in any medium, provided the original work is unaltered and is properly cited. The written permission of Cambridge University Press must be obtained for commercial re-use or in order to create a derivative work.

\title{
The Non-Democratic Roots of Mass Education: Evidence from 200 Years
}

\author{
AGUSTINA S. PAGLAYAN University of California, San Diego
}

$B$ ecause primary education is often conceptualized as a pro-poor redistributive policy, a common argument is that democratization increases its provision. But primary education can also serve the goals of autocrats, including redistribution, promoting loyalty, nation-building, and/or industrialization. To examine the relationship between democratization and education provision empirically, I leverage new datasets covering 109 countries and 200 years. Difference-in-differences and interrupted time series estimates find that, on average, democratization had no or little impact on primary school enrollment rates. When unpacking this average null result, I find that, consistent with median voter theories, democratization can lead to an expansion of primary schooling, but the key condition under which it does - when a majority lacked access to primary schooling before democratization-rarely holds. Around the world, state-controlled primary schooling emerged a century before democratization, and in threefourths of countries that democratized, a majority already had access to primary education before democratization.

$\mathbf{E}$ ducation shapes many of the things we care about most. Around the world, its provision is a political matter. Governments regulate, fund, and manage schools, and they choose policies that affect the quantity and quality of schooling. Judging by the quantity of primary schooling available, the historical record paints a remarkably positive picture of governmental intervention in education. While in the early twentieth century only a handful of countries provided universal access to primary education, today most exhibit universal primary school enrollment rates.

A large literature in political science and economics argues that "the spread of democratic voting rights played a leading role in explaining ... the rise of primary schooling" (Lindert 2004, 105). The argument

Agustina S. Paglayan, (D) Assistant Professor, Department of Political Science and School of Global Policy and Strategy, University of California, San Diego, apaglayan@ucsd.edu.

This paper received the 2019 APSA/JCPA Best Comparative Policy Paper Award. I thank the Stanford Interdisciplinary Graduate Fellowship and the Center for Global Development for funding; David Stasavage for sharing replication data and code for Figure A9 of Online Appendix A; Claire Adida and Ken Scheve for reading and commenting on multiple drafts; Ran Abramitzky, John Ahlquist, Nancy Birdsall, Carles Boix, Renee Bowen, Lawrence Broz, Alberto Diaz-Cayeros, Thad Dunning, James Fearon, Edgar Franco, Francisco Garfias, Jane Gingrich, Florian Hollenbach, Martin Huici, Sean Ingham, David Laitin, David Lake, Susanna Loeb, Megumi Naoi, Gareth Nellis, Lant Pritchett, Adam Przeworski, Justin Sandefur, Jeremy Weinstein, seminar participants at the Stanford-Berkeley Political Economy Workshop, the 2017 LSE-Stanford Conference on Long Range Development in Latin America, RIDGE Economic History 2018, APSA 2018, the UCSD Political Economy Lunch Group, Brookings Institution, the Center for Global Development, the Inter-American Development Bank and the World Bank, as well as the APSR Editors and three anonymous reviewers, for very helpful feedback.

Received: June 01, 2018; revised: April 10, 2020; accepted: June 25, 2020. builds on median voter theories linking democratization and redistribution: because a transition from autocracy to democracy entails a shift in political power from rich to poor, democratization will lead to more pro-poor redistributive policies. ${ }^{1}$ Primary schooling, the literature argues, is "the sharpest edge of progressive redistribution" (Ansell 2010, 2); "the kind of taxbased education that redistributed the most from rich to poor" (Lindert 2004, 107). Hence the poor will demand more of it, and politicians will address this demand in societies where the poor can vote (e.g., Ansell 2010; Brown and Hunter 2004; Lindert 2004; Stasavage 2005). While recent studies of the determinants of healthcare provision, ${ }^{2}$ land reform, ${ }^{3}$ income and wealth taxation, ${ }^{4}$ and welfare spending ${ }^{5}$ have questioned the idea that democracies redistribute more than autocracies, democracy remains salient in explanations of why some governments provide more primary education than others, backed by a consistent empirical finding that democratization and suffrage extensions are associated with higher primary school enrollment rates and spending (Ansell 2008, 2010; Avelino, Brown, and Hunter 2005; Brown 1999; Brown and Hunter 1999, 2004; Harding and Stasavage 2014; Kaufman and Segura-Ubiergo 2001; Lake and Baum 2001; Lindert 2002, 2004; Mariscal and Sokoloff 2000; Stasavage 2005). Indeed, recent surveys of the literature characterize the argument that democracies provide higher quantities of education as an established truth (Busemeyer and Trampusch 2011; Gift and Wibbels 2014, 294; Hoffman 2015).

\footnotetext{
${ }^{1}$ Acemoglu and Robinson (2006a); Boix (2003); Meltzer and Richard (1981)

${ }^{2}$ Ross (2006)

${ }^{3}$ Albertus (2015)

${ }^{4}$ Mares and Queralt (2015); Scheve and Stasavage (2016).

${ }^{5}$ Ansell and Samuels (2014).
} 
This article challenges the idea that democratization was a leading force driving the global expansion of primary schooling. When using median voter theories to predict an expansion of primary schooling after democratization, past studies implicitly assume that the median voter lacked access to primary schooling before democracy emerged. This testable assumption has not been empirically examined, and there are reasons to doubt its validity. First, primary schooling can be perceived as an attractive policy even by governments who are not interested in pro-poor redistribution. Governments have expanded primary schooling to foster industrialization (Gellner 1983), forge a national identity (Alesina and Reich 2013; Darden and Grzymala-Busse 2006; Weber 1976), promote loyalty and domestic order (Cantoni et al. 2017; Paglayan 2017), or strengthen military power (Aghion et al. 2019; Darden and Mylonas 2015; Ramirez and Boli 1987), among other goals. Second, non-democratic regimes that espouse a left-wing ideology or rely on support from the poor to maintain power may provide mass primary schooling to redistribute from rich to poor (Kosack 2013; Manzano 2017). Whatever the reasons for the provision of primary schooling under non-democratic regimes, if the median voter determines policy choices in a democracy, and the median voter already had access to primary schooling before democracy emerged, then transitioning to democracy should not lead to an expansion of primary schooling; democracy should lead to an expansion of primary schooling only when the median voter previously lacked access to it. The question, then, is how widespread was access to primary schooling before countries democratized?

Drawing on new country-level datasets spanning 200 years of education provision, this article documents that most of the expansion of primary schooling took place before democracy emerged. On average, central governments began to regulate primary education about a century before a country's first transition to democracy, and over two-thirds of school-age children were already enrolled in primary school a decade before democratization. Difference-indifferences and interrupted time series estimates provide evidence consistent with the prediction that in countries where a majority of the population already had access to primary schooling before democracy emerged, democratization led to an increase in secondary but not in primary schooling, even though a sizable minority of the population remained excluded from primary education. Democracy did lead to an expansion of primary schooling in countries where a majority of the population lacked access to primary schooling; these, however, represent only one-fourth of all democratizing countries.

Why, then, do past studies conclude that the empirical evidence indicates that democracy led to an expansion of primary schooling? I show that this conclusion stems from methodological limitations affecting these studies' internal and/or external validity due to (i) the absence of controls for long-standing country-level characteristics that could simultaneously affect a country's political and educational trajectories, (ii) the absence of controls for the global upward trend in the quantity of primary education provision observed during the post-war period, both in countries that democratized and in those that did not, (iii) limited geographic coverage focusing on a single region or country, and/or, crucially, (iv) reliance on school enrollment or spending data from the 1960s on, raising questions about the relationship between regime type and education provision in earlier periods - central in the case of state-controlled primary education systems, which have been around for well over a century (Ansell and Lindvall 2013). In sum, we lack empirical research that convincingly assesses the presence of a causal relationship between democracy and primary schooling for a large number of countries and regions over a period that encompasses most of the history of public schooling.

Once we examine the long history of primary school systems worldwide and address the methodological issues limiting past studies' internal validity, democracy no longer plays a leading role in explaining the global expansion of primary schooling. While democratization can promote the expansion of primary schooling, the key condition under which it does - when a majority of the population lacked access to primary schooling before democracy emerged-seldom holds. The rise and spread of primary school systems took place mostly under non-democratic regimes.

These findings underscore the importance of future research on the non-democratic roots of mass education and have implications for the literatures on the political economy of development, the politics of redistribution, modernization theory, and the determinants of public goods provision.

\section{THEORIES OF DEMOCRACY AND EDUCATION REVISITED}

A common prediction in political economy theories of education provision is that democratization, especially the extension of voting rights to the poor or non-rich, will lead to the expansion of primary schooling because (1) a majority of voters in the new democracy will demand increased access to primary schooling to improve their (and their children's) economic position and (2) politicians in a democracy will be more responsive to this demand than autocrats. The main criticism of redistributive arguments of this type is that the assumption that politicians in democracies are responsive to the policy preferences of the median voter is unrealistic.

This article makes a different point: it argues that, even if democratically-elected politicians are responsive to the median voter-and I find evidence suggesting that, in the realm of education provision, they

\footnotetext{
${ }^{6}$ Ross (2006) finds that, after including country and year fixed effects, there is no longer evidence that democracy reduces infant or child mortality, suggesting the need for a similar study on education.
} 
FIGURE 1. Main Argument and Alternative Theories

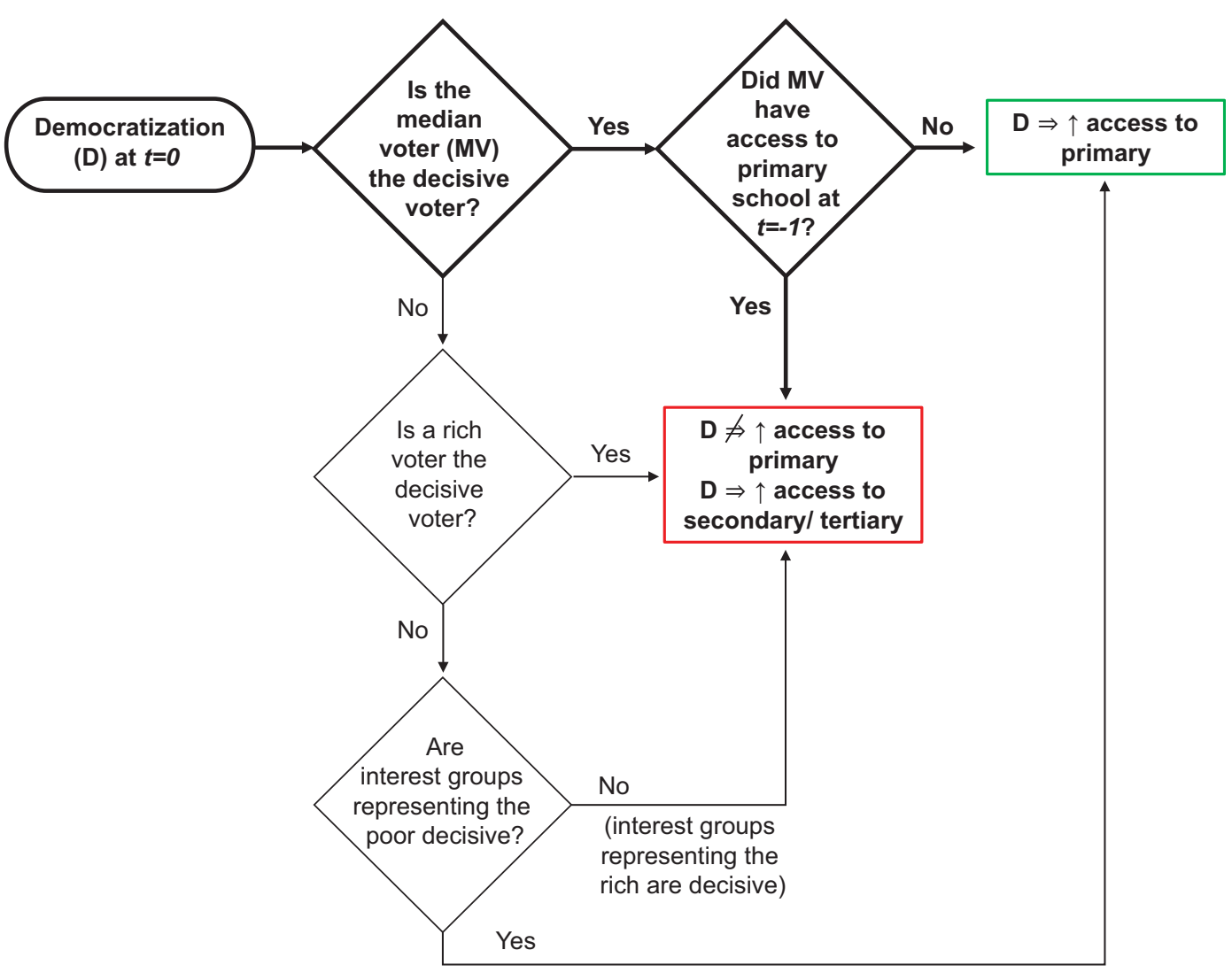

Note: Main argument in bold; alternative theories in regular font.

are - this does not imply that democratization will lead to an expansion of primary schooling because it is possible that the median voter already had access to primary schooling before acquiring the right to vote. That is, I don't object to the assumption that democratically elected politicians are influenced by what the majority of voters want but rather to the prediction that this implies an expansion of primary schooling.

In a median voter framework, I argue, the prediction about how democratization will impact the quantity of primary schooling depends on how much provision there was before and, specifically, whether or not the median voter already had access to primary schooling prior to democratization. If they did, then median voter theories would predict no expansion of primary schooling as a result of democratization - but we might see an increase in secondary or tertiary education provision if the median voter lacked access to these. By contrast, median voter theories would predict increased provision of primary schooling if the median voter lacked access to it before democratization. These predictions are laid out in the bolded section of the flowchart in Figure 1. The average effect of democratization on access to primary education will be a weighted average of the effect of democratization under the two scenarios and will depend on the proportion of countries that fall under each scenario.

\section{Alternative Theories}

The literature also suggests alternative explanations that are important to consider about why democratization might not lead to an expansion of primary schooling besides the possibility that the median voter already had access to it. Later, I will test these alternative theories empirically. Many of these alternative theories argue that the median voter is not decisive in a democracy. First, it could be that democracies respond to the interests of wealthy voters, who are more likely to vote and lobby, and can capture the policy-making process by purposefully designing institutions prior to a democratic transition to prevent future redistribution (Albertus and Menaldo 2014; Ansell and Samuels 2014). If this were the case, we would not expect democratization to lead to an expansion of primary schooling, but it could lead to increased secondary and/or tertiary education. Second, it could be that elected politicians respond not to voters (rich or poor) but to organized interest groups such as corporate lobbyists or labor unions (Gilens and Page 2014). If this were the case, the effect of democratization on 
education provision would depend on whether the interest groups that represent the preferences of poor and uneducated voters are sufficiently strong to influence policy (Kosack 2013). ${ }^{7,8}$

In sum, while median voter theories of redistribution and theories of democratic capture (by rich voters or interest groups representing them) are often presented in contrast to one another, with the former predicting increased pro-poor redistribution after democratization and the latter predicting no increase in redistribution, I argue that median voter theories' prediction about the effect of democratization on the quantity of primary education will depend on the level of provision before democratization. In particular, democratization will lead to increased access to primary education if the median voter previously lacked access to it, but not otherwise. To predict the overall effect of democratization, then, a crucial question is how much provision of primary schooling existed across countries before they transitioned to democracy. The next section surveys existing theories of why there might have been high levels of provision of primary education under non-democratic regimes.

\section{PRIMARY SCHOOL SYSTEMS UNDER NON-DEMOCRACIES}

As mentioned in the introduction, this article documents that, worldwide, most of the expansion of primary schooling occurred before democracy emerged. While this may be a counterintuitive finding to many political scientists and economists, historians have documented several cases of mass provision of primary education under non-democratic regimes, starting with Prussia in the eighteenth century and including the USSR in the twentieth. In this section, I survey the

\footnotetext{
${ }^{7}$ Additionally, where race or ethnicity are a more salient political cleavage than socioeconomic class, democratic politicians may have incentives to exclude some groups from access to education (Kramon and Posner 2016; Miguel 2004).

${ }^{8}$ Some scholars have also criticized median voter theories' assumption about demand for education, noting that individuals may sometimes not demand education even if they lack access to it (Bursztyn 2016; Platas 2019), either because they underestimate the economic returns to schooling or because they value education but cannot afford to make it a priority given their more pressing short-term needs. Platas (2019) finds that parents in Malawi estimate the economic returns to four years of primary schooling to be the same as no schooling at all. Jensen (2010) and Nguyen (2008) provide experimental evidence that parents underestimate the returns to schooling in Dominican Republic and Madagascar, respectively. Bursztyn (2016, 1101) provides evidence from a survey experiment in Brazil that "poor decisive voters prefer the government to allocate resources ... [to] favor redistributive programs that increase their incomes in the short run, such as cash transfers" over educational investments, not because they do not value education but because they "have more urgent needs" and cannot "afford to have fewer resources for present consumption in order to have more education for their children" (Bursztyn 2016, 1125). The possibility that poor parents might be reluctant to send their children to primary schools due to short-term financial constraints is especially relevant in pre-industrial societies where children contributed to farming and agriculture (Brockliss and Sheldon 2012).
}

history and social science literatures to parse out four common arguments about the reasons for the provision of mass education under non-democracies. For each argument, I add qualitative historical evidence from primary sources presented in online annotations and quantitative exploratory tests presented in Online Appendix B. Together, this evidence suggests that autocrats often expected benefits from providing primary schooling to the masses.

Before proceeding, it is important to note that, although there is a prevalent notion in political science that primary education is a "good" or "service" that increases the skills of the poor, schooling and skills need not go hand in hand. The dissociation that exists between schooling and skills is the subject of many empirical studies in development economics and economics of education (Angrist et al. 2019; Hanushek and Woessmann 2015; World Bank 2018) and is illustrated in Figure 2. Across countries, the correlation between the quantity of schooling (measured by average years of schooling among young individuals) and students' math skills (measured by average country scores on PISA) is 0.07. A weak correlation (0.26) also exists between education spending and math skills. This dissociation underscores an aspect of education provision that is insufficiently integrated into political economy theories: ${ }^{9}$ politicians may increase the quantity of schooling for reasons other than to improve the level of skills. ${ }^{10}$

Building on the work of historians, other social scientists, and my own work, I argue that while nondemocratic regimes' decision to provide primary education for the lower classes sometimes stems from an incentive (1) to improve the skills and income of the poor (i.e., pro-poor redistribution), other times it can stem from an incentive (2) to mold the political values and behaviors of the masses and convince them to be content with the status quo as part of an effort to enhance the regime's legitimacy and stability, and/or (3) to improve the average level of skills in the population as part of a state effort to promote industrialization or military power.

\section{Molding Political Values and Behaviors}

Some of the earliest and most famous cases of state intervention in primary education by non-democratic regimes, including 1760s Prussia and 1830s France, focused on shaping the moral character of the poor (Paglayan 2017). Prussia extended compulsory primary schooling in rural areas through a Royal Decree signed by Frederick II in 1763. France passed its first Primary Education Act in 1833 during the July Monarchy. In both countries, elites used the term "moral education" to describe the main goal behind their decision to establish a public primary school system. Moral education included a range of goals such as inculcating "loyalty,

\footnotetext{
${ }^{9}$ See Harding and Stasavage (2014) for an exception.

${ }^{10}$ Additionally, education policies may seek, but fail, to promote skills.
} 


\section{FIGURE 2. Quantity and Quality of Education, by Country}

Panel A: Student Achievement and Years of Schooling

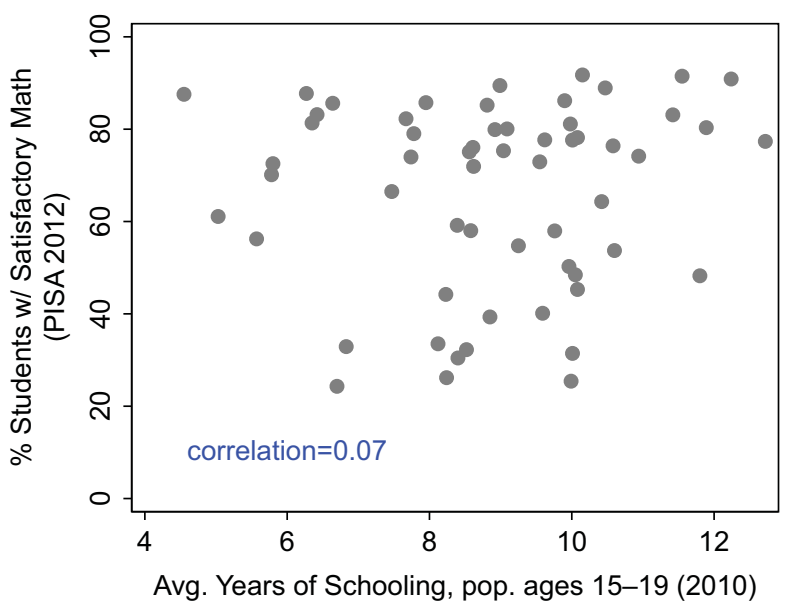

Panel B: Student Achievement and Education Spending

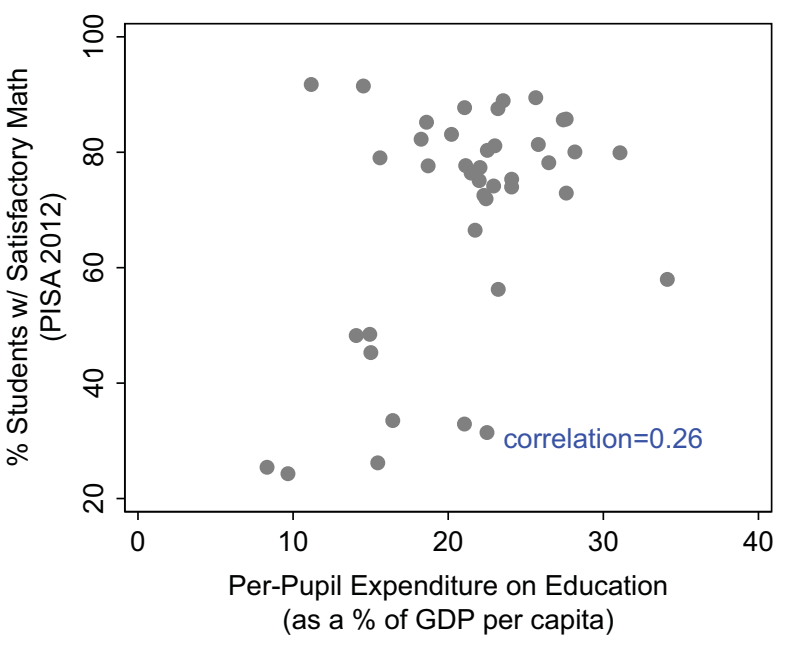

Note: Sources: Barro and Lee (2013); PISA (2012); and World Bank EdStats.

obedience, and devotion" to the sovereign, fostering "the attachment of citizens to the fundamental laws of the state," disseminating a national identity to forge unity, teaching a common language to facilitate compliance with state directives, and making citizens "willing to bear their share of the national burden" by paying taxes and fighting for their country (Alexander 1919; Barkin 1983; Brockliss and Sheldon 2012; Brownson 1839; Guizot 1860; Melton 1988; Ramirez and Boli 1987; Reisner 1922; Weber 1976). In these early state efforts to organize and provide primary schooling, "there appears to have been little interest in expanding the pool of well-educated workers" (Brockliss and Sheldon 2012, 92; see also Budde 2012; Squicciarini and Voigtlander 2015; 2016). Elites also "showed little interest in using schooling to promote social mobility" (Brockliss and Sheldon 2012, 92). In fact, some rulers stated that primary schools should be careful not to promote industrialization or social mobility. ${ }^{11}$

A similar theme emphasizing the benefits of moral education for the poor can be found among nineteenthcentury elites in Latin America (Paglayan 2017). Argentina and Chile, whose policies influenced educational debates throughout the region, passed their first law establishing a national primary education system in 1884 and 1860 , respectively, both under tight oligarchic regimes. In both countries, the political debates on whether to establish a centralized primary education system provide ample evidence that elites across the ideological spectrum saw shaping the moral character of the poor as the most promising contribution of a public system of mass primary education (Egaña Baraona

\footnotetext{
${ }^{11}$ Using data from the World Values Survey (multiple years), Figure B1 shows a positive relationship between an individual's educational attainment and their willingness to fight for their country in autocracies but not in democracies.
}

2000; Guevara, Paglayan, and Perez-Navarro 2018; Montt 1859; Sarmiento 1845; 1849; Tedesco 1986).

While the idea that non-democratic regimes can use schooling to shape political values and behaviors and sustain the status quo has a long tradition among historians, in political science the more dominant view - promoted by modernization theories - has been that schooling empowers individuals to demand political rights (Almond and Verba 1963; Lipset 1960) and, therefore, autocrats seeking to maintain their power will block its expansion to the masses (Bourguignon and Verdier 2000). Recent exceptions in political economy that highlight autocrats' use of mass schooling to indoctrinate future citizens include Cantoni et al. (2017), Darden and Grzymala-Busse (2006), Paglayan (2017), and Testa (2018).

\section{Skills for Industrialization and Military Strength}

While in the examples discussed above elites seldom mentioned the goal of industrialization, autocrats in other parts of the world, especially during the twentieth century, turned to the provision of mass primary schooling partly to support state-led industrialization. The USSR and China are key examples. In the USSR, primary education expanded dramatically under Stalin in the 1920s and 30s and was perceived as crucial "for the success of such projects as the Five Year Plans ... Industrial development needed more skilled workers of all kinds. No possible source of talent could be left untapped, and the only way of meeting these needs was by the rapid development of a planned system of mass education" (Grant 1964, 22). The Soviet regime's deliberate expansion of mass education in support of industrialization, military, and world supremacy was what most impressed the U.S. education missions to 
the USSR in the 1950s (U.S. Department of Health, Education, and Welfare 1959; 1960). In China, primary schooling expanded at an unprecedented rate in the 1950s. The Communist Party reshaped the curriculum partly to increase labor productivity by teaching practical technical skills to transform China from a backward economy to a major economic power (Elliott 1982). To be sure, primary schools in both countries sought not only to increase workforce skills but also to shape future citizens' political values to make them willing to work and fight for their country. ${ }^{12}$

In principle, nothing prevents democratically elected politicians from also providing mass primary education to shape future citizens' political values and behaviors or to develop a more skilled workforce or military. However, Olson (1993) and Acemoglu and Robinson (2006b) theorize that autocratic rulers' longer time horizons may give them stronger incentives to adopt policies whose benefits accrue mostly over the long run. Educational investments may be especially sensitive to politicians' time horizons because it usually takes many years before these investments can translate into a more loyal citizenry or a more industrialized economy.

\section{Redistribution from Rich to Poor}

Autocracies may also expand the provision of primary schooling to redistribute from rich to poor if they embrace a left-wing ideology or need the lower class to survive. Manzano $(2017,128)$ criticizes standard theories because they assume that "a dictatorial government ... tends to defend the interests of the rich, who prefer a limited public intervention in educational provision." She argues that "there are autocratic experiences in which dictators appeal to the less affluent sectors of society as their bases of support" (Manzano 2017,40 ) and documents that $46 \%$ of all dictatorships between 1960 and 2000 championed a left-wing ideology that favored the interests of the poor (Manzano 2017, 111). Kosack's (2013) examination of education policy making in Ghana, Brazil, and Taiwan from 1930 to 2000 reveals that autocrats who assumed power after organizing and mobilizing the poor were especially bold in their efforts to expand access to primary schooling. ${ }^{13}$

\section{Global Ideas about the Role of Education}

Besides the motivations discussed so far for why non-democratic regimes might deliberately expand primary schooling, these systems could also have expanded under non-democracies by coincidence as a result of forces affecting all regimes, not just

\footnotetext{
${ }^{12}$ Exploratory quantitative tests provide mixed evidence for the industrialization argument. Figure B2 shows that central governments began to regulate primary schooling during pre-industrial times, whereas Figure B3 suggests that industrialization increased after central governments began to regulate primary schooling.

${ }^{13}$ Using data on the ideology of governments from Brambor, Lindvall, and Stjernquist (2017), Figure B4 provides suggestive visual evidence that transitioning from a non-leftist to a left-wing nondemocracy leads to an increase in primary school enrollment rates.
}

non-democracies. A key driver of this secular expansion proposed by sociologists is the diffusion of ideas about the importance of primary education systems to support nation-state formation and economic development. During the nineteenth century, European rulers became convinced that their success in building a nation-state required a state-controlled primary school system that taught people a common language and set of political values. This idea traveled quickly and took root in other parts of the world, including autocracies but also democratic countries like the United States (Boli, Ramirez, and Meyer 1985; Green 1990; Ramirez and Boli 1987). It was just a historical coincidence, the argument goes, that at the time when this idea was circulating, most regimes were still non-democratic. More recently, especially since the development of human capital theory in the 1960s, the term "education" has become increasingly associated with economic development (Bonal 2016; Brockliss and Sheldon 2012; Green 1990). Competition for economic, technological, and military supremacy during the Cold War, and the active dissemination by international organizations like the U.N. and the World Bank of ideas highlighting education's role in fostering economic growth, may have accelerated the expansion of primary schooling during the post-war period-again, regardless of the type of regime. For instance, in 1990, 140 countries signed the Convention on the Rights of the Child agreeing to commit themselves to ensure free access to primary education for all. ${ }^{14}$

In sum, there are multiple reasons why we might observe provision of primary schooling under nondemocratic regimes-some pointing to deliberate attempts by these regimes to shape political values, skills, or the distribution of wealth and others pointing to provision under non-democratic regimes by coincidence, as a result of the spread of ideas about the benefits of education for nation- and state-building at a time when most existing regimes were non-democratic. From the perspective of what median voters theories will predict about the effect of democratization on access to primary schooling, it does not matter why there was provision of it under non-democratic regimes; what matters is how much provision there was and whether a majority of the population already had access to it before democratization. Later on, I will show that access to primary schooling in most autocracies that became democracies was high.

\section{EXISTING EMPIRICAL RESEARCH}

Table A1 of Online Appendix A summarizes the data, methods, and conclusions of past studies. As noted in

\footnotetext{
${ }^{14}$ Figure B5 provides suggestive visual evidence that the expansion of primary schooling under non-democracies was not merely a historical coincidence. These regimes appear to have incentives of their own to expand primary schooling, as suggested by the observation that reversals from democracy to non-democracy are, on average, followed by an acceleration of primary school enrollment rates that is not observed in countries that remain democratic. I thank Reviewer 1 for suggesting this empirical test.
} 
recent surveys of the literature (Gift and Wibbels 2014; Hoffman 2015), one of the most consistent empirical findings in cross-national studies of the relationship between regime type and education provision is that democracies provide higher quantities of education than non-democracies, especially primary education. While the literature usually argues that democracy leads to increases in enrollment rates and education expenditures, the methods used warrant caution against causal interpretations. First, some early studies likely overestimate democracy's effect because they lack controls for long-standing country characteristics that could explain why some countries both became democratic and have higher levels of education provision. ${ }^{15}$ It could just be that certain countries had cultural, economic, or political characteristics that prompted them both to provide a lot of primary education and, eventually, to democratize.

Acknowledging this, most studies include country fixed effects in the analysis, which prevents us from confounding the effect of democracy with the effect of permanent country characteristics affecting both who democratizes and how much education is provided. While these studies find that within a country, transitions from autocracy to democracy are followed by an increase in primary school enrollment rates, school attendance, and primary education expenditures (e.g., Ansell 2008; Harding and Stasavage 2014; Stasavage 2005), this evidence is still insufficient to isolate the effect of democracy. We also need to net out the role of common shocks or events that could have led to the secular expansion of education in democracies and autocracies alike, including, for example, the role of Cold War competition, international organizations, and the global diffusion of ideas about the benefits of education discussed above. This is what including year fixed effects allows us to do. Ross (2006) finds that after accounting not just for country but also for year fixed effects, there is no longer evidence that democracy lowers infant or child mortality. However, few peerreviewed studies of the relationship between democracy and education provision include both country and year fixed effects, and those that do arrive at conflicting conclusions, perhaps because they cover different periods and sets of countries (e.g., Lindert [2004] studies developed countries from 1880-1930; Lott [1999] analyzes 99 countries over 1985-92).

Finally, because World Bank and UNESCO education statistics are available from the 1960s on, most studies focus on this recent period. The few peerreviewed studies that explore the relationship between democracy and education provision over a longer period raise questions about external validity due to their limited geographic coverage: Lindert (2004)

\footnotetext{
${ }^{15}$ E.g., Brown (1999) compares primary school enrollment in democracies and non-democracies in 136 countries from 1960-1987, finds democracies have higher enrollment rates than non-democracies with similar observable characteristics such as GDP per capita, and concludes that "institutions associated with individual rights and electoral competition have an important effect on primary school enrollment" (681, emphasis mine).
}

focuses on OECD countries, Mariscal and Sokoloff (2000) on the Americas, and Aghion et al. (2019) on Europe.

In sum, we lack empirical research that convincingly assesses the presence of a causal relationship between regime type and the quantity of education provision for a large number of countries and over a period that encompasses most of the history of state-controlled education systems. This article seeks to help fill this important gap.

\section{RESEARCH DESIGN}

To assess the role of democratic institutions in explaining the global expansion of primary education, the article proceeds in four steps. First, I examine what came first, states' interest in the provision of primary education or democracy. To determine when states became interested in primary education, I employ two historical datasets: an original dataset documenting the year when central governments in 33 European and Latin American countries began to regulate the provision of primary education and a dataset compiled by Lee and Lee (2016) with information about the year when central governments in 109 countries began to monitor primary education systems by collecting statistics about the number of students enrolled in school.

Second, I ask the following: besides regulating and monitoring schools, to what extent did non-democratic regimes expand access to primary education? To measure the quantity of provision, I use the most common measure in the literature, country-level primary school enrollment rates (SERs). Two new historical datasets (Lee and Lee 2016; Paglayan 2017) spanning from 1820 to 2010 enable me to examine the relationship between regime type and primary education provision over a much longer period than has been possible before.

Third, I use difference-in-differences and interrupted time series methods to estimate the effect of democratization on primary SERs. I examine democracy's average effect over the whole period (1820-2010) and separately for democratic transitions taking place before or after 1945. The 1945 cutoff is informed by two factors. First, primary SERs across developing countries accelerated after that year (Figure A2). Examining whether democratization contributed to this acceleration is an important question. Second, as discussed earlier, others have argued that the idea that education can contribute to individual earnings and economic development only became widespread after World War II. As a result, demand for education during the post-war may have been stronger, and-if democracies respond to popular demand-the effect of democratization may have been stronger, too.

Fourth, I use difference-in-differences models that allow for heterogeneous treatment effects of democratization to test which of the three theories discussed earlier (median voter, capture by rich voters, capture by organized interest groups representing the rich) best explains the findings on the average effect of democratization. 


\section{HISTORICAL DATASETS}

\section{Timing of Initial State Intervention in Primary Education}

State intervention in primary education systems can take many forms. For 33 countries in Europe and Latin America, I used country-specific history of education books, articles, and Ph.D. dissertations published in English, Spanish, or Portuguese, supplemented by consultations with history of education experts, ${ }^{16}$ to code the year when central governments began to (i) fund primary schools, (ii) manage them, (iii) establish a mandatory curriculum for all primary schools, (iv) establish certification requirements for primary school teachers, (v) train prospective teachers, (vi) mandate local authorities to provide universal access to schooling, (vii) mandate free provision for the poor, and (viii) establish compulsory primary education. Data collection details and brief country narratives are available in Online Appendix C. Because central governments sometimes began intervening in primary education after subnational governments, the dataset may not always capture the earliest expression of politicians' interest in education, but it allows us to make conservative statements of the form "politicians were interested in primary schooling at least as far back as X."

To extend the analysis to all regions, I examine an additional form of governmental intervention in education involving the use of official inspections and gathering of school-level statistics to monitor the state of primary schooling. Lee and Lee (2016) identify the first year when official statistics about student enrollment in public primary schools became available in 111 countries - of which 109 can be matched to information about regime type. Other forms of state intervention - e.g., provision of funding or introduction of a mandatory curriculum - usually occurred before official enrollment statistics became available, so again, the timing of these statistics provides a conservative estimate that "politicians were interested in primary schooling at least as far back as X."17

\section{School Enrollment Rates (SERs)}

I employ two datasets that measure primary SERs. The first is an original country-level dataset constructed by Paglayan (2017) containing annual primary SERs as a proportion of the population ages 5-14 for 38 countries in Europe and Latin America from 1828 to 1945, though there is variation in the start date due to variation in the timing of emergence of state-controlled primary education systems. The construction of this dataset involved contrasting and merging historical

\footnotetext{
${ }^{16}$ Text sources provide $91 \%$ of the data; expert consultations, conducted when the dates could not be found in texts in English, Spanish, or Portuguese, provide $9 \%$ of the data.

${ }^{17}$ See Online Appendix D for additional evidence on the appropriateness of using Lee and Lee's (2016) data on the timing of education statistics to make inferences about the timing of state intervention in primary education vis-à-vis the timing of democratization.
}

data on student enrollment from several secondary sources (Benavot and Riddle 1988; Mitchell 2007; Flora 1983; the U.S. Bureau of Education's annual Reports of the Commissioner of Education for 1872-1915) and supplementing these with country-specific primary and secondary sources. The second dataset, assembled by Lee and Lee (2016), contains quinquennial countrylevel data on primary school enrollment rates as a proportion of the school-aged population for 111 countries from 1820 to 2010. The authors merged post-war data on primary SERs from UNESCO with more historical data compiled from similar-but not the same-sources I used.

Each dataset has its advantages and limitations and using both helps me assess the robustness of the conclusions. On one hand, my dataset starts earlier. Although Lee and Lee provide extrapolated SERs for all countries since 1820 , in reality only nine countries in their dataset have nonextrapolated pre- 1870 data, compared with 17 countries in mine. Indeed, my dataset contains one extra decade of historical data for Argentina, Brazil, and England; two decades for Costa Rica, Ecuador, France, and Spain; and four decades for Austria, Germany, and Norway. On the other hand, their dataset covers all regions. Although data preceding 1870 are scarce in Lee and Lee (2016), 63 countries in their dataset have enrollment data beginning in 1900, 85 have data preceding 1920, and 105 preceding 1950. This enables us to improve on the external validity of past studies that employ data from UNESCO or the World Bank, which are only available after the 1960s.

I also examine the relationship between democratization and secondary and tertiary enrollment rates using data from Lee and Lee (2016).

\section{Democratization}

I use three sources to measure democratization: the Polity Project; Boix, Miller, and Rosato (2012; hereafter, BMR); and the Political Institutions and Political Events (PIPE) Data Set by Przeworski et al. (2013). For comparability with past studies, which mostly use polity2 (which considers whether there are open and competitive elections and constraints on the Executive), I construct a binary measure following the convention that a country is democratic if polity 2 ranges between 6 and 10. As an alternative measure of increases in the political voice of the poor, I use the introduction of universal male suffrage, obtained from PIPE. For a less demanding measure, I use BMR, which counts as democratic any country that has competitive elections and has enfranchised more than $50 \%$ of adult males. The main text presents results based on Polity to facilitate comparison with past studies, but the main conclusions hold when considering all measures.

\section{STATE-CONTROLLED PRIMARY SCHOOL SYSTEMS EMERGED UNDER AUTOCRACIES}

Comparing the timing of democratization and initial state intervention in primary education reveals that, 
worldwide, states began to intervene in primary education well before the poor were enfranchised.

In Europe and Latin America, central governments began to intervene in primary education on average 107 years before democratization as measured by Polity or BMR and 91 years before the introduction of universal male suffrage. In general, the earliest interventions entailed funding and managing schools. About a decade later, central governments began to establish curriculum and teacher certification requirements and established a monopoly over teacher training. Education statistics appeared about another decade later. Compulsory primary schooling laws were usually the latest form of state intervention but were still introduced about 52 years before democratization and 36 years before universal male suffrage. These findings are not driven by a few isolated cases; they reflect a general pattern shown in Figure 3 (Panel A). Orange triangles indicate when a compulsory education law was first passed. Red dots indicate when any other form of central government intervention in primary education first took place. Blue squares indicate the timing of democratization as measured by Polity. The pattern is clear: the red dots precede the orange triangles, which precede the blue squares. ${ }^{18}$

The same pattern appears outside of Europe and Latin America. For 109 countries, Panel B of Figure 3 shows that political authorities began to monitor and gather official statistics about primary school systems on average 61 years before democratization in Europe and Latin America and 63 years before democratization elsewhere.

\section{SIZABLE EXPANSION OF PRIMARY SCHOOLING UNDER AUTOCRACIES}

How elites regulated public primary education early on created enduring patterns of authority and organization (Ansell and Lindvall 2013). Curriculum plans and teacher training programs established under non-democracies sometimes remained in place decades after democratization (Guevara, Paglayan, and Perez-Navarro 2018).

But states didn't just regulate or monitor primary education; they also expanded its provision even in the absence of mass elections. Among countries that experienced at least one transition to democracy, on average $60 \%$ of children were already enrolled in primary school two decades before the country's first democratic transition, $70 \%$ were enrolled just before democratization, and no dramatic change in the enrollment trend occurred after democratization. This is shown in Panel A of Figure 4; the thick black line represents the average primary SER twenty years before and after a country's first transition to democracy. Indeed, in all regions except Sub-Saharan Africa a large majority of children were already enrolled in primary school at least two decades before

\footnotetext{
${ }^{18}$ Figure A3 looks at other forms of education intervention and measures of democracy.
}

democratization; and in all regions, democratization was not followed by a sharp acceleration of primary school enrollment rates. These observations hold regardless of how we measure democracy (Figure A4). Additionally, in every region, a majority of children gained access to primary schooling well before there was a regional move toward democracy (Figure A6).

These patterns are not driven by a few non-democratic regimes in each region. In $65 \%$ of countries that ever transitioned to democracy, a majority of schoolage children were already enrolled in primary school 20 years before the first democratic transition. That proportion climbs to $75 \%$ of countries if we look at enrollment 10 or 5 years before democratization (Figure 4, Panel B).

In sum, non-democratic regimes regulated, monitored, and provided high quantities of primary education. In most countries, a majority of children were already enrolled in primary school well before the first transition to democracy.

\section{AVERAGE EFFECT OF DEMOCRACY ON ACCESS TO PRIMARY EDUCATION}

Figure 5 provides visual evidence suggesting that, on average, democratization had little or no positive effect on primary SERs. The figure displays, in black, the average SER among democratizing countries before and after their first transition to democracy and, in gray, the average trend in comparison countries that, at any given point in time, were nondemocratic. ${ }^{19}$ Panel A displays these trends for the entire period 1820-2010, Panel B for democratizations that occurred between 1820 and 1945, and Panel C, for those occurring after 1945.

Beginning with the full period 1820-2010, Panel A shows that, historically, countries that became democratic already had higher primary SERs before transitioning to democracy, but democratization was not followed by a faster increase in SERs in democracies compared to non-democracies. A similar pattern emerges when using universal male suffrage or BMR's measure of democracy (Figure A7).

The conclusion is the same if we focus on more recent democratizations, but Panel C helps us understand why past studies that did not include year fixed effects in the analysis concluded differently. The left-side graph depicts average SERs before and after democratization; the right side illustrates the same trends but with the $y$-axis ranging from $0-100 \%$ (like Panels A and B). ${ }^{20}$ Recall that most studies compare education provision before and after democratization within countries that democratize, accounting for country, but not year, fixed effects. This is analogous to focusing on the black line only, which shows that democratic

\footnotetext{
${ }^{19}$ See bottom of Figure 5 for details about the construction of the comparison group.

${ }^{20}$ Figure A15 shows the variation behind the average trends depicted in Panel C.
} 


\section{FIGURE 3. Timing of Democratization and State Intervention in Primary Education, by Country}

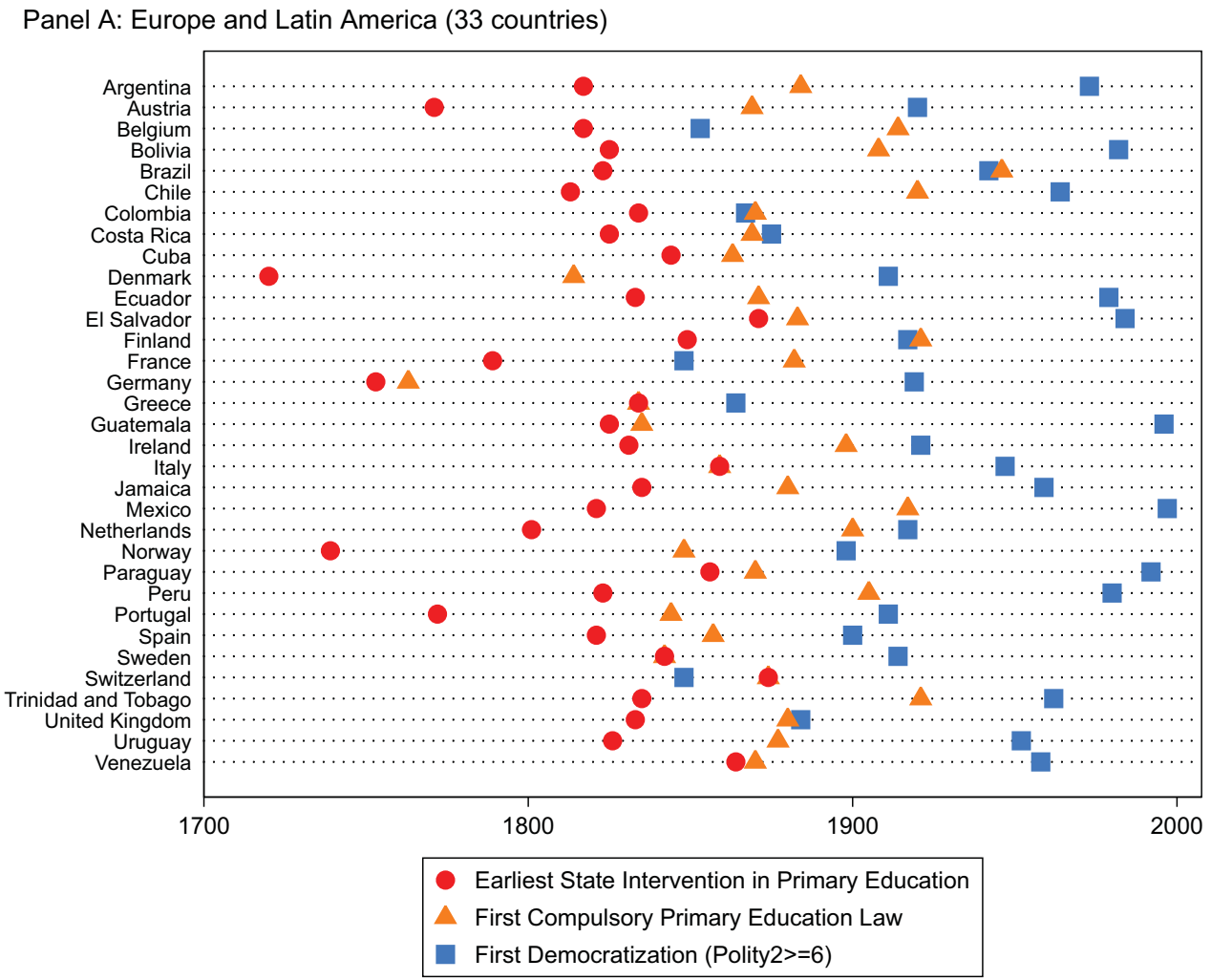

Panel B: All Regions (109 countries)
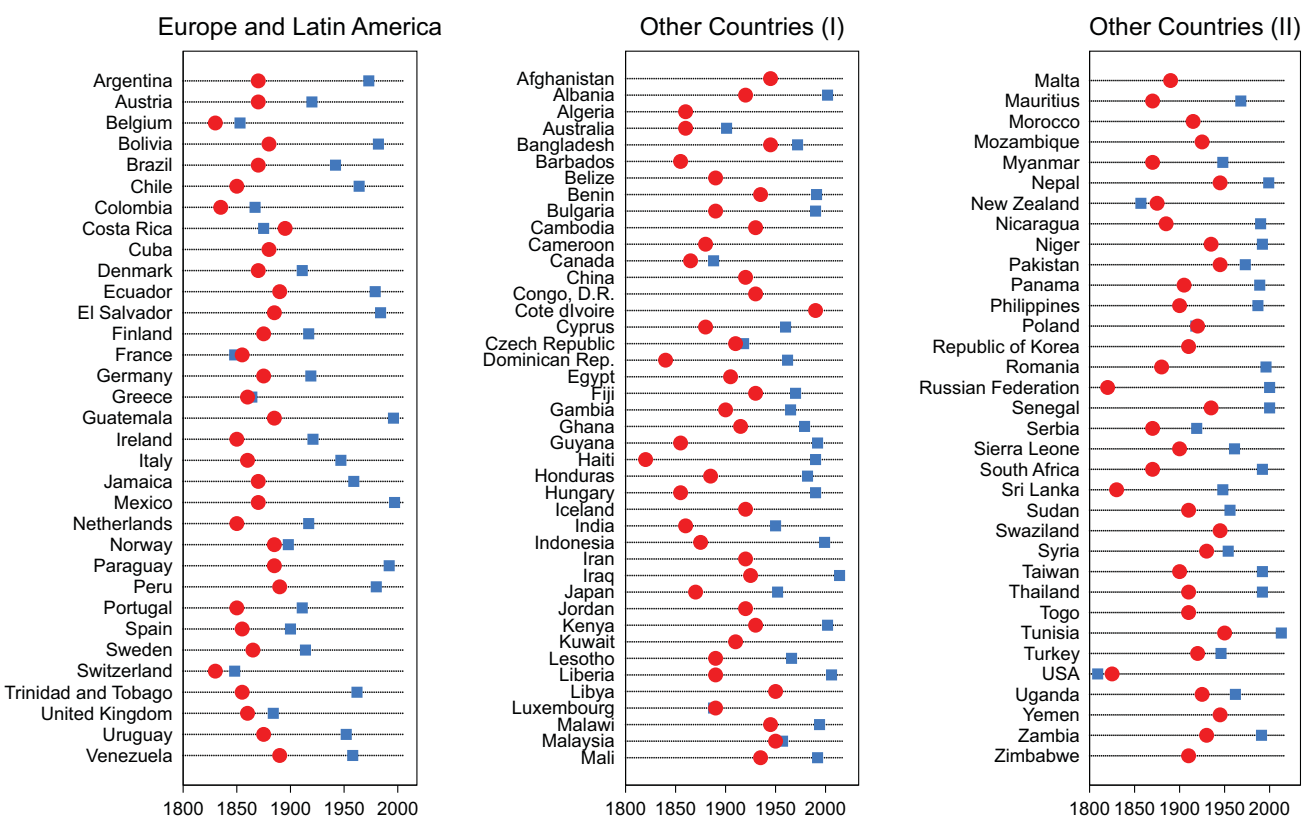

Earliest Primary Education Statistics (Lee \& Lee)

First Democratization (Polity2>=6)

Sources: Author for timing of primary education interventions in Panel A (see Online Appendix C); Lee and Lee (2016) for timing of primary school enrollment statistics in Panel B; Polity Project for timing of democracy. 


\section{FIGURE 4. Primary School Enrollment Rates in Countries that Experienced Democratization, 1820-2010}

Panel A: Average Enrollment Rates Before and After

Democratization, World and Regionals Means

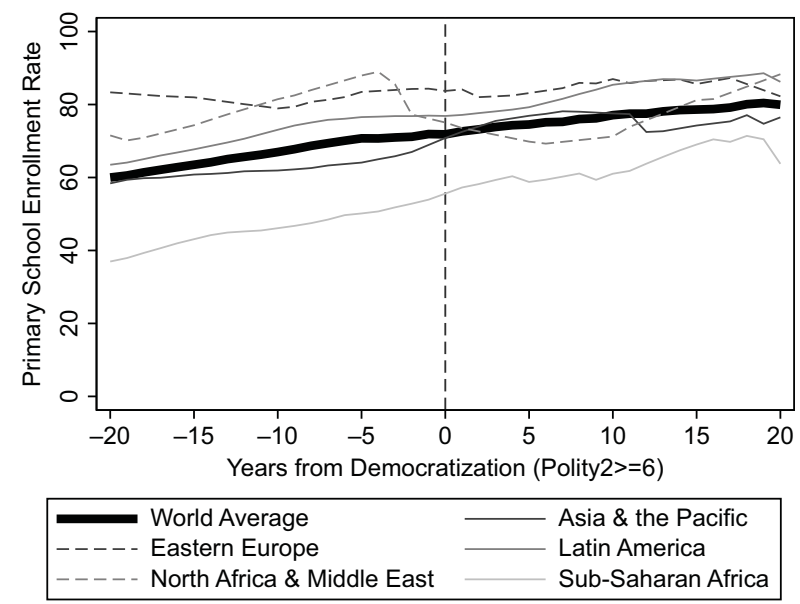

Panel B: Distribution of Enrollment Rates

5 Years Before Democratization

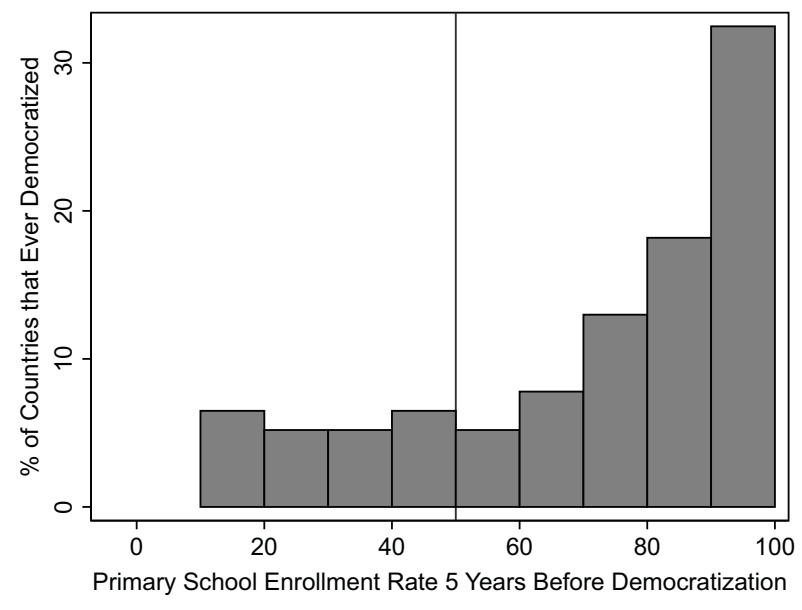

Note: For visualization purposes, in Panel A quinquennial data on enrollment rates were linearly interpolated to obtain annual estimates. Trends based on the original (quinquennial) data are shown in Figure A5. Sources: Lee and Lee (2016) for enrollment rates; Polity Project for timing of democracy.

transitions coincided with an acceleration of education provision. While looking at the black line alone might lead us to conclude that democratization caused that acceleration, the gray line shows that countries that did not democratize experienced the same acceleration. The inclusion of year fixed effects helps net out any common time shocks driving educational expansion across all regime types. Not accounting for this secular global trend would lead us to overestimate democratization's impact. ${ }^{21}$

There is also no visual evidence to conclude that democratic transitions occurring before 1945 had a positive effect on primary school coverage. Panel B shows that in countries that became democratic between 1820 and 1945, primary SERs were higher and growing faster compared with non-democratic countries before they adopted democratic institutions, but once democracy emerged, there is no longer a divergence in SERs between democratic and non-democratic countries.

To quantify the average influence of democratization on primary SERs and compute confidence intervals around the estimated effects, I use difference-indifferences (DD, Equation 1) and interrupted time series with a comparison group (ITS, Equation 2):

$$
Y_{i, t}=\gamma_{i}+\phi_{t}+\delta_{1} \cdot T_{i, t}+\epsilon_{i, t}
$$

\footnotetext{
${ }^{21}$ Including country and year fixed effects would leave no variance to be explained if almost every country was democratizing and experiencing educational expansion. However, that is not the case here: by the end of the period of analysis, 68 countries are democratic and 41 are non-democratic. The year fixed effects simply model the trend in school enrollment rates among non-democratic countries, enabling us to estimate the counterfactual trend for democratic countries in the post-democratization period.
}

and

$$
\begin{gathered}
Y_{i, t}=\gamma_{i}+\phi_{t}+\beta_{0}\left(\text { year }_{i, t}-\text { year }_{i}^{*}\right) \cdot \operatorname{Ever}_{i} \\
+\beta_{1} \operatorname{EverD}_{i} \cdot P_{i, t}+\beta_{2}\left(\text { year }_{i, t}-\text { year }_{i}^{*}\right) \cdot \operatorname{EverD}_{i} \cdot P_{i, t}+\epsilon_{i, t},
\end{gathered}
$$

where $\gamma_{i}$ accounts for country fixed effects and $\phi_{t}$ accounts for year fixed effects. In the DD model (Equation 1), $T_{i, t}$ equals 1 if country $i$ in year $t$ was a democracy and equals 0 otherwise; $\delta_{1}$ is the average treatment effect of democratization on primary SERs under the identifying assumption that SERs in countries that democratized, had they not done so, would have changed just as much as they did in countries that did not become democratic. Visual evidence of parallel pre-treatment trends in Panels $\mathrm{A}$ and $\mathrm{C}$ of Figure 5 suggests that $\mathrm{DD}$ is a valid approach when estimating the average effect of democratization for the full period (1820-2010) and for the post-war period (1945-2010). However, the absence of parallel pre-treatment trends in Panel B highlights the need to use a different causal inference method for 1820-1945. I use ITS for that period.

In an ITS model, the identifying assumption is not that the trend of treated countries would have been parallel to that of comparison countries absent democratization but that treated countries' trend in the post-treatment period would have changed by the same (linear) amount as comparison countries' trend had they not experienced democratization (Shadish, Cook, and Campbell 2002). In Equation 2, $\left(\right.$ year $_{i, t}-$ year $\left._{i}^{*}\right)$ is the number of years relative to democratization in country $i$, Ever $D_{i}$ equals 1 if country $i$ ever democratized during the period of analysis and equals 0 otherwise, and $P_{i, t}$ takes a value of 1 if country $i$ had already democratized in year $t$ and equals 0 otherwise. The $\phi_{t}$ 


\section{FIGURE 5. Average Primary School Enrollment Rates before and after Democratization, Treated and Comparison Countries, 1820-2010 and Subperiods}

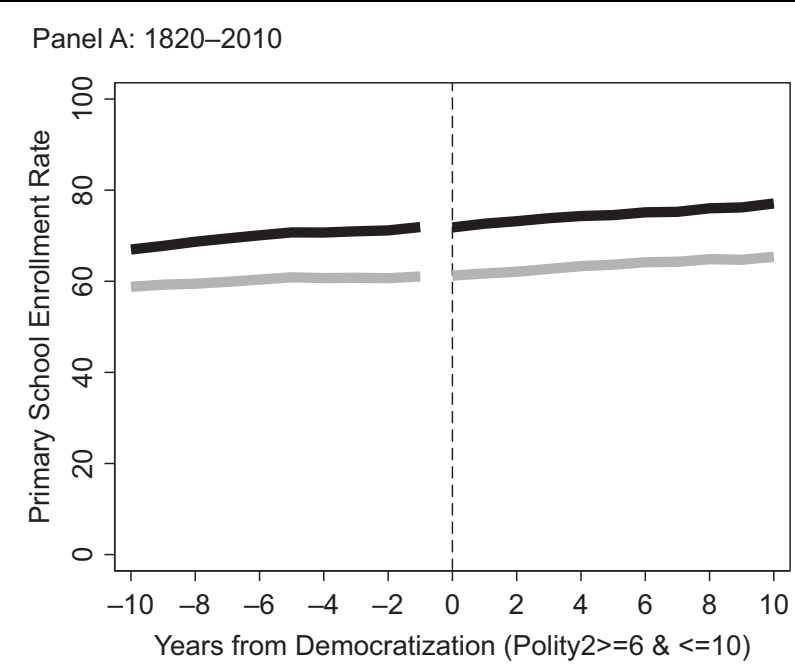

Panel B: 1820-1945
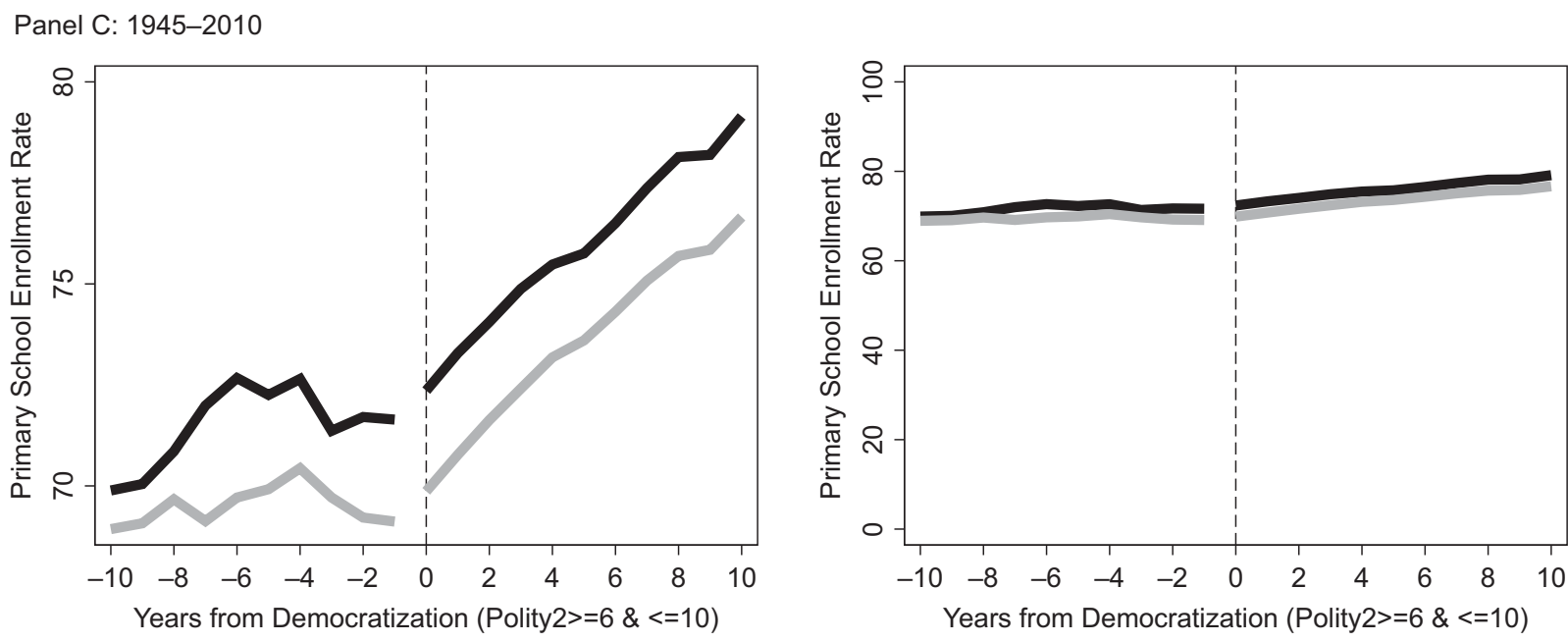

Note: Democratizing countries' trend in black; non-democracies' in gray. For visualization purposes, quinquennial enrollment rates at the country level were interpolated to obtain annual estimates. For each country that democratized in year $t=T$, I compute the average primary school enrollment rate of a comparison group, which in any given year $t$ is composed of countries that were non-democratic in that year. I then compute the average primary school enrollment rate across all comparison groups, depicted by the gray line.

Sources: Lee and Lee (2016) for enrollment rates; Polity Project for timing of democracy.

dummies trace out the trend of comparison countries, and $\beta_{0}$ is the linear difference in the pre-treatment trend between treated and comparison countries, $\beta_{1}$ is the average one-time shift in treated countries' trend in the first year under democracy, and $\beta_{2}$ measures the linear change in the slope of treated countries' trend after democratization. Under the identifying assumption, $\left(\beta_{1}+\mathrm{k} . \beta_{2}\right)$ measures the effect of democracy $k$ years after democratization. This magnitude can be thought of as the difference between treated and comparison countries in the difference between their post-treatment slopes net of differences in their pre-treatment slopes. Intuitively, if treated countries' enrollment rate was already growing faster than control countries' in the pre-democracy period and diverged even more during the post-democratization period, we would interpret the additional amount of divergence as the positive effect of democratization. Conversely, if we observed that, after democracy, treated countries' trend diverged less from control countries' than in the pre-democracy period, we would interpret the reduction in the amount of divergence as the negative influence of democratization on SERs.

The results of Equations 1 and 2, shown in Figure 6, provide limited support for the claim that democratization led to an average increase in primary SERs. Panel A plots the coefficient on democracy obtained from (i) a regression with country fixed effects but not year fixed effects, the most common method used in prior studies, (ii) a DD model including both country and year fixed effects (Equation 1), and (iii) a model that adds country-specific linear time trends to Equation 1, to control for observable and unobservable features of a country that change linearly over 
FIGURE 6. Estimated Effect of Democratization on Primary School Enrollment Rates, 1820-2010 and Subperiods

Panel A: Difference-in-Differences Estimates

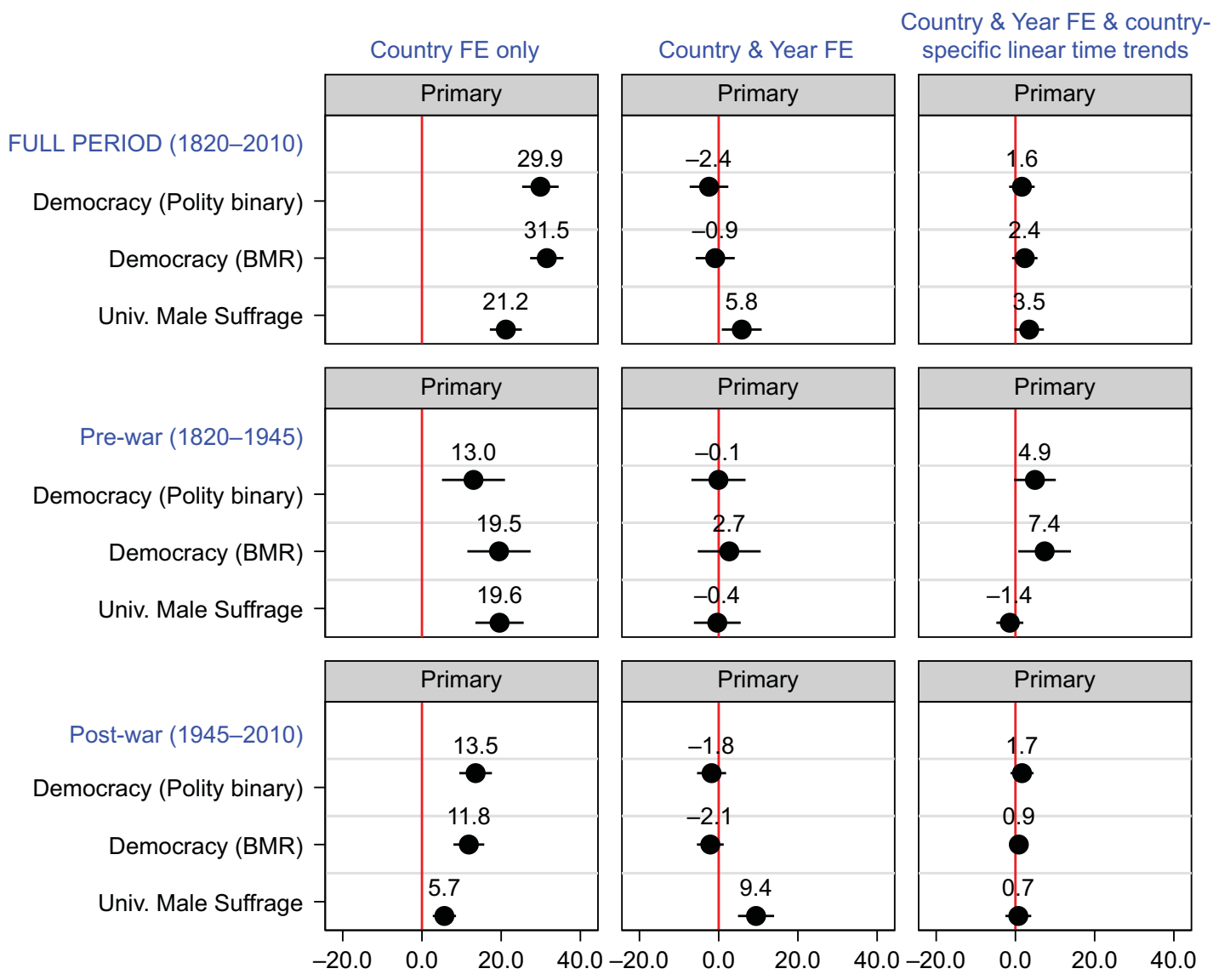

Panel B: Interrupted Time Series Estimates
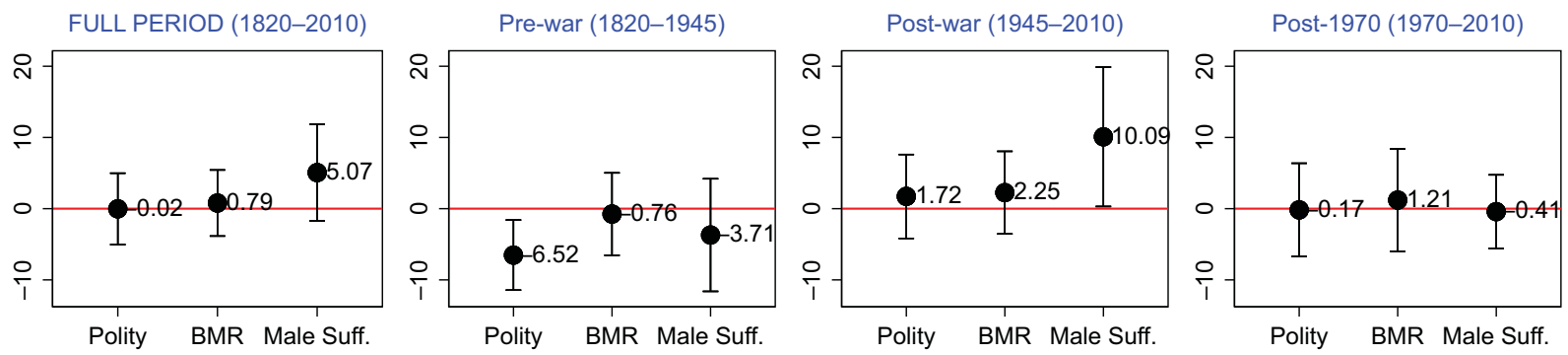

Note: Point estimates and $95 \%$ confidence intervals from standard errors clustered at the country level. In Panel B, point estimates reflect the effect of democracy within 10 years of democratization. A total of 109 countries contribute data to estimate the equations that span the entire period (1830-2010) and the post-war period (1945-2010); 98 countries contribute data to estimate the equations that focus on the pre-war period (1830-1944). Sources: Lee and Lee (2016) for enrollment rates; Polity Project, BMR, and Przeworski et al. (2013) for timing of democracy.

time. Panel B provides the estimated influence of democracy 10 years after democratization based on the ITS model, particularly relevant for the period 1820-1945. 95\% confidence intervals based on standard errors clustered at the country level are reported.

The results for the full period 1820-2010 do not provide support for the claim that democratization played a leading role in explaining the global expansion of primary schooling. Panel A confirms that accounting for country but not for year fixed effects leads us to severely overestimate democracy's influence on primary SERs. For instance, using Polity to measure democracy, as most past studies do, the results with only country fixed effects suggest that democratization increases primary SERs by 30 percentage points (p.p.). However, once year fixed effects are added, the 
coefficient on democracy is no longer statistically different from zero and the point estimate is negative. Moreover, all the coefficients on democracy, regardless of which of the three measures of democracy is used, are estimated with enough precision to rule out the claim that democracy was an important driver of the expansion of primary schooling. Recall that the average primary school enrollment in democratizing countries already exceeded $70 \%$ before democratization, so even if we take the upper bound of the $95 \%$ confidence interval in models with country and year fixed effects (5.7 p.p. on average across the three measures of democracy) or models including also country-specific linear time trends (5.8 p.p. on average), the estimated effect of democratization would represent a substantively small effect.

A more appropriate comparison with prior studies is to focus on the effect of democratizations occurring during the post-war period, 1945-2010. Again, Panel A of Figure 6 shows that estimating the influence of these democratic transitions using country but not year fixed effects overestimates democracy's effect. Once year fixed effects are added, the estimated coefficient for democracy becomes negative and is no longer statistically significant if democracy is measured using either Polity or BMR. The only measure of democracy that appears to have a positive effect on primary SERs is the introduction of universal male suffrage, but as with the results for the full period, this effect also becomes statistically insignificant once we account for countryspecific linear time trends.

Finally, for democratic transitions occurring between 1820-1945, the DD estimates in Panel A overestimate the effect of democracy because they overlook that primary SERs were growing faster in democratizing countries prior to democratization. If we account for the difference in the pre-treatment slopes and assume that this difference would have remained the same in the absence of democratization, our conclusion about the influence of democracy changes considerably. As Panel B of Figure 6 shows, ITS estimates of the effect of democratization do not support the claim that democracy leads to an expansion of primary SERs. The point estimates for all measures of democracy are negative (and statistically significant in the case of Polity). Moreover, even if we take the upper bound of the $95 \%$ confidence interval from the ITS models (2.5 p.p. on average across the three measures of democracy), this represents a substantively small effect considering that the average primary school enrollment in countries that democratized between 1820-1945 was already above $70 \%$ before democratization.

\section{Robustness}

The preceding findings provide limited support for the claim that democracy, on average, leads to an expansion of primary schooling. The conclusion that democracy did not play a leading role in driving the expansion of primary schooling holds if we (i) use Tobit instead of OLS to correct for the possibility of sample selection bias due to the presence of a censored (upward- bounded) dependent variable (Table A2), (ii) look at the effect of continuous changes in regime type instead of using binary measures of democracy (Table A3), (iii) employ a different historical dataset of primary SERs for the 1820-1945 period (Figure A8), (iv) use public spending on primary education (available from Stasavage 2005) instead of enrollment rates to measure the quantity of primary education provision (Figure A9), and (v) examine the effect of democratization separately for each region (Figure A10; Table A4).

\section{DISENTANGLING THE AVERAGE NULL EFFECT OF DEMOCRACY: THE ROLE OF PROVISION BEFORE DEMOCRATIZATION}

At least three different theories discussed earlier predict the absence of an average positive effect of democratization on primary SERs: democratic capture by rich voters, democratic capture by interest groups representing rich voters, or democratic responsiveness to a median voter who already had access to primary schooling before democratization. Of these three theories, the evidence presented in this section is most consistent with the median voter-based explanation.

As a first step, I estimate the effect of democratization on secondary and tertiary education enrollment rates and find evidence of a positive, statistically significant average effect of democracy on secondary SERs, especially when considering democratizations occurring after 1945 (Panels B and C of Figure A11). Because the upper class is more likely to demand secondary than primary education, it may be tempting to conclude that democracy did not lead to the expansion of access to primary education but led to the expansion of secondary schooling due to capture of the democratic policy-making process by the rich or by interest groups representing the rich.

However, three pieces of evidence suggest that capture theories are not adequate for explaining the dynamics of education provision after democratization.

First, to assess the possibility that the average null effects of democracy on primary SERs are explained by a median voter framework, I re-estimate Equation 1 for the full period allowing for heterogeneous treatment effects of democracy depending on whether or not a majority of children were enrolled in primary school before democratization. Panel A of Table 1 reports OLS results. Panel B reports Tobit results.

The results provide some support for median voter theories. In countries where most children lacked access to primary education before democratization, a transition to democracy leads to increases in primary SERs based on two of three measures of democracy (BMR and universal male suffrage) and to reductions in the provision of secondary and tertiary education. However, a majority of children lacked access to primary schooling before democratization in only one-fourth of countries that democratized; in the remaining threefourths, a majority of children already had access to primary schooling (but not to secondary education) 


\begin{tabular}{|c|c|c|c|c|c|c|}
\hline \multirow[b]{3}{*}{ Independent variable: } & \multicolumn{3}{|c|}{ Panel A: OLS } & \multicolumn{3}{|c|}{ Panel B: Tobit } \\
\hline & Primary & Secondary & Tertiary & Primary & Secondary & Tertiary \\
\hline & \multicolumn{3}{|c|}{ School enrollment rate } & \multicolumn{3}{|c|}{ School enrollment rate } \\
\hline \multicolumn{7}{|l|}{ Polity 2 between 6 and 10} \\
\hline $\begin{array}{l}\text { democracy } \\
\text { democracy } x \text { majority enrolled in primary }\end{array}$ & $\begin{array}{c}5.3 \\
(3.5623) \\
-8.6^{\star} \\
(4.1463)\end{array}$ & $\begin{array}{c}-5.1 \\
(3.2870) \\
13.2^{\star \star} \\
(3.9961)\end{array}$ & $\begin{array}{r}-2.6 \\
(2.6150) \\
3.6 \\
(3.2115)\end{array}$ & $\begin{array}{c}5.1 \\
(3.0542) \\
-8.0^{\star} \\
(3.8664)\end{array}$ & $\begin{array}{l}-5.2 \\
(3.3095) \\
13.1^{\star \star} \\
(4.0243)\end{array}$ & $\begin{array}{r}-2.6 \\
(2.5901) \\
3.6 \\
(3.1808)\end{array}$ \\
\hline \multicolumn{7}{|l|}{ Democracy (BMR) } \\
\hline $\begin{array}{l}\text { democracy } \\
\text { democracy x majority enrolled in primary }\end{array}$ & $\begin{array}{l}8.0^{*} \\
(3.2197) \\
-9.7^{\star \star} \\
(3.4496)\end{array}$ & $\begin{array}{l}-12.2^{\star \star} \\
(2.7032) \\
18.2^{\star \star} \\
(3.0982)\end{array}$ & $\begin{array}{c}-7.2^{* \star} \\
(2.2573) \\
6.1^{\star} \\
(2.4868)\end{array}$ & $\begin{array}{c}6.2^{\star} \\
(2.9740) \\
-7.2^{\star} \\
(3.4015)\end{array}$ & $\begin{array}{l}-12.4^{\star \star} \\
(2.7360)^{* \star} \\
18.2^{\star *} \\
(3.1331)\end{array}$ & $\begin{array}{c}-7.2^{* \star} \\
(2.2366) \\
6.1^{*} \\
(2.4640)\end{array}$ \\
\hline \multicolumn{7}{|l|}{ Universal male suffrage (PIPE) } \\
\hline $\begin{array}{l}\text { democracy } \\
\text { democracy } x \text { majority enrolled in primary }\end{array}$ & $\begin{array}{l}15.7^{\star \star} \\
(3.1897) \\
-10.2^{\star \star} \\
(2.9843)\end{array}$ & $\begin{array}{l}-17.3^{\star \star} \\
(2.6090) \\
18.7^{\star \star} \\
(2.6514)\end{array}$ & $\begin{array}{c}-9.4^{* *} \\
(1.4518) \\
3.1^{\star} \\
(1.2598)\end{array}$ & $\begin{array}{l}15.9^{\star \star} \\
(3.3165) \\
-9.9^{\star \star} \\
(3.3067)\end{array}$ & $\begin{array}{l}-17.3^{\star \star} \\
(2.6001) \\
18.5^{\star \star} \\
(2.6297)\end{array}$ & $\begin{array}{c}-9.4^{* *} \\
(1.4394)^{3.1} \\
(1.2490)\end{array}$ \\
\hline $\begin{array}{l}\text { Note: Results based on a linear difference-in- } \\
\text { depending on the level of primary school enro } \\
\text { country level are in parentheses. Stars denote } \\
\text { rates; Polity Project, BMR, and Przeworski et a }\end{array}$ & $\begin{array}{l}\text { model with } \\
\text { prior to dem } \\
\text { gnificance at } \\
\text { timing of de }\end{array}$ & $\begin{array}{l}\text { d year fixed } \\
\text { ?. Ordinary le } \\
\text { and }{ }^{\star *} 0.01 \text { le }\end{array}$ & $\begin{array}{l}\text { ilar to the o } \\
\text { es estimates } \\
\text { umber of cou }\end{array}$ & $\begin{array}{l}\text { Equation } \\
\text { nd Tobit es } \\
\text { outing data }\end{array}$ & $\begin{array}{l}\text { ng for heterc } \\
\text { anel B). Stan } \\
\text { rces: Lee an }\end{array}$ & $\begin{array}{l}\text { reatment ef } \\
\text { clustered } \\
\text { 6) for enroll }\end{array}$ \\
\hline
\end{tabular}




\section{FIGURE 7. Average Primary School Enrollment Rates before and after Democratization, Treated Countries by Whether or Not a Majority of Children Were Already Enrolled in Primary Schooling before Democratization, and Comparison Countries, 1820-2010}
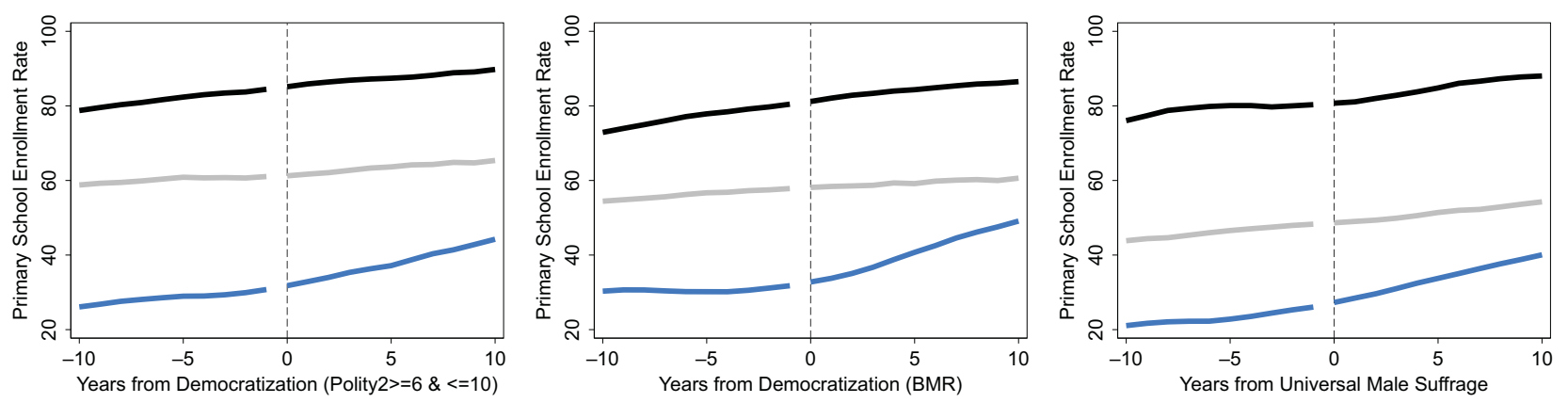

Note: Average primary school enrollment rate in democratizing countries where a majority of children were enrolled in primary education before democratization (black line), in democratizing countries where a majority of children were not enrolled in primary education before democratization (blue), and in control countries (light gray). Sources: Lee and Lee (2016) for enrollment rates, Polity Project, BMR, and Przeworski et al. (2013) for timing of democracy.

FIGURE 8. Primary Education in Uruguay and Chile before and after Democratization
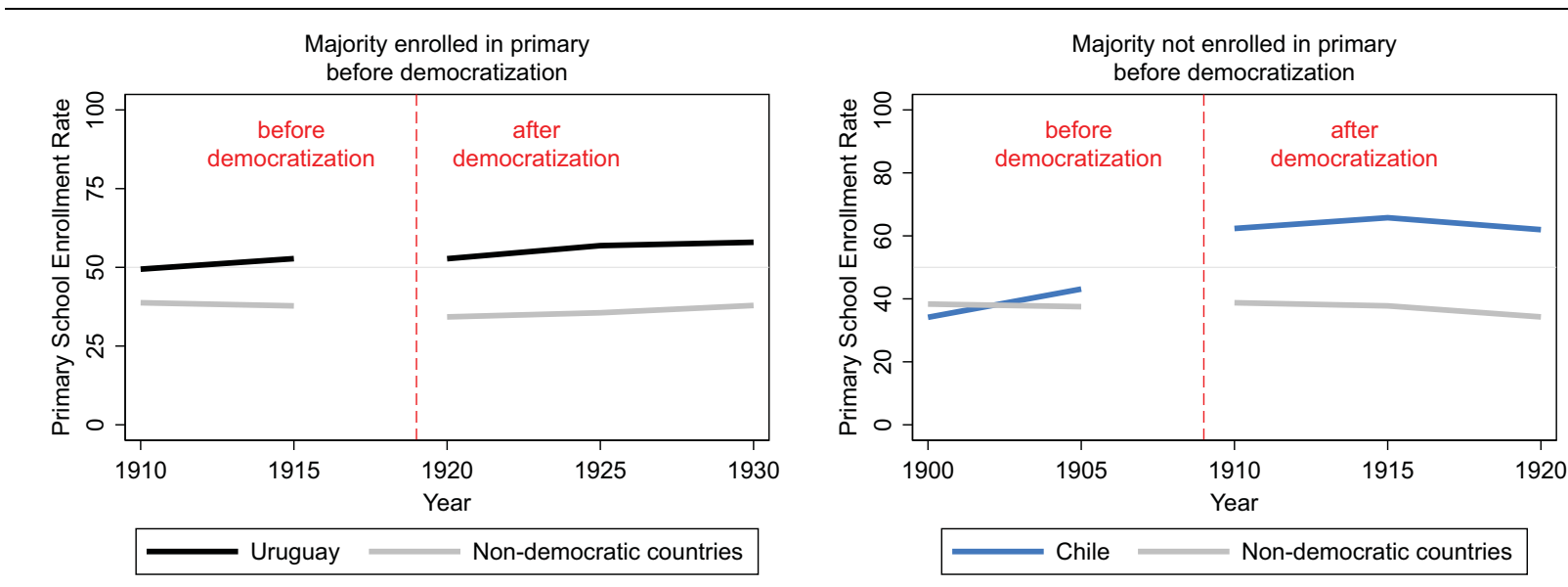

Sources: Lee and Lee (2016) for enrollment rates; BMR for timing of democratization.

before democracy emerged. Here, in line with the theoretical predictions of a median voter framework, democratization does not lead to an increase in primary SERs based on two of three measures of democracy (Polity and BMR) but leads to increased enrollment in secondary education. Figure 7 provides visual evidence of these effects.

To illustrate these dynamics, consider Chile and Uruguay, two countries with similar levels of economic development, state capacity, and colonial history, and whose first transition to democracy occurred at a similar time. However, in Uruguay, a majority of the population had access to primary schooling before democracy emerged; in Chile, they did not. Figure 8 shows that, in line with median voter theories, primary schooling barely increased in Uruguay after democratization, but it expanded considerably in Chile.

Second, to further assess the likelihood that capture theories explain the main results, I follow Albertus and Menaldo's (2014) empirical approach, which assumes that democratic capture by the rich is likely when the rich can anticipate a transition to democracy but not when democracy is precipitated by an unexpected social revolution. Estimating a linear difference-indifferences model that allows for heterogeneous treatment effects of democracy depending on whether or not democratization was immediately preceded by a revolution, I find no support for the claim that there is a difference in the effect of democratization on primary, secondary, or tertiary enrollment rates depending on whether or not elites can anticipate, and therefore capture, a transition to democracy (Table A5).

Third, I test the argument that democracy's impact depends not on the median voter's previous access to primary schooling but on the existence of a powerful organization representing the interests of the poor. Ideally, we would want cross-national time-series data about the degree to which labor unions and other mass organizations influence the policy-making process. The Varieties of Democracy dataset provides a measure of 
the relative power of different socioeconomic groups at the time of democratization, but based on this variable (v2pepwrsoc), there are no countries where, at the time of democratization, non-elites wielded considerable power. As an alternative, to measure differences in the degree to which the poor are represented in the new democracy, I estimate heterogeneous treatment effects of democracy by whether or not the new democratic government was left-wing or not, using data from the "Ideology of Heads of Government, 1870-2012" dataset by Brambor, Lindvall, and Stjernquist (2017). The results do not provide consistent evidence for the claim that there is a difference in the effect of democratization on primary SERs depending on whether or not the new democratic government is left-wing (Table A6).

In sum, the absence of an average positive effect of democracy on primary SERs, and the presence of an average positive effect on secondary SERs, can be explained best within the framework of theories of redistribution in which the median voter determines policy decisions. Theories proposing that rich voters and organizations representing the interest of the rich control education policy making receive less empirical support. ${ }^{22}$

\section{DISCUSSION}

Why do past studies conclude that democratization led to the expansion of primary schooling? This section considers how the research design of four influential studies - Brown (1999), Lindert (2004), Mariscal and Sokoloff (2000), and Stasavage (2005)-affected their conclusion. Using Lee and Lee's (2016) dataset, I first estimate models similar to those estimated in each study; then, where relevant, I add country fixed effects (Brown 1999; Mariscal and Sokoloff 2000) and/or year fixed effects (Brown 1999; Mariscal and Sokoloff 2000; Stasavage 2005).

I find that Brown's (1999) conclusion that democratization increases primary SERs among developing countries in 1960-1987 and Stasavage's (2005) conclusion that democratization in Africa led to greater primary education spending no longer hold once we include year fixed effects (Figure A9 and Panel B of Figure A12). For Mariscal and Sokoloff (2000), I find that the exclusion of both country and year fixed effects explains their finding that democratization increases primary enrollment in the Americas during 1860-1945

\footnotetext{
${ }^{22}$ The three theories tested in this section assume that individuals are self-interested. However, altruistic individuals may demand primary education for others even if they themselves already have access to it. I thank Reviewer 3 for noting this possibility. Figure A13 provides a test of this argument. Building on existing research suggesting that women are more altruistic and more likely to care about children in general than men, I use difference-in-differences to test the prediction that granting suffrage rights to women leads to increases in primary SERs. The persistence of a positive and statistically significant coefficient on universal female suffrage even in models with country and year fixed effects is consistent with the argument that democratization may lead to the expansion of primary schooling when voters have altruistic values.
}

(Figure A12, Panel C). I do find some visual evidence suggesting that Lindert's conclusion that democratization led to an average increase in primary SERs is valid for the sample he analyzed (21 countries from 18801930). However, even in these countries, most of the expansion of primary schooling occurred before democratization. Overlooking this fact led Lindert to overstate democracy's role, claiming that it played "a leading role" in explaining the rise of primary schooling (Figure A12, Panel A).

\section{CONCLUSION}

This article challenges the centrality given to democracy in explanations of why some governments provide more primary education than others. Using new historical datasets to examine the relationship between primary education and democracy in 109 countries over a 200-year period and methods that improve on past studies' efforts to address concerns about omitted variable bias, I find that, consistent with the predictions of median voter theories of redistribution following democratization, transitions to democracy lead to a (small) increase in primary school coverage only when a majority of the population lacked access to primary schooling under non-democracy. However, this condition rarely holds. In three-fourths of countries that experienced democratization, a majority of the population already had access to primary schooling before democratizing. In these cases, democratization does not lead to further expansion of primary education.

The findings contribute to the literature on the comparative politics of education provision and have implications for the literatures on redistribution under democracies, the determinants of public goods provision, modernization theory, and authoritarian politics. They also underscore the importance of future research on the non-democratic roots of mass education.

First, while a common argument is that democratization does not translate into pro-poor redistributive policies because the policy-making process is captured by the upper classes (Albertus and Menaldo 2014; Ansell and Samuels 2014; Ross 2006), this article suggests that the effect of democratization on the quantity of primary education provision is better explained by median voter theories than by theories of democratic capture by the rich. Democracies are responsive to the majority - but at a cost to the poorest in society: when the majority already has access to primary schooling before democratization, democratic governments do not expand access to primary education even if a sizable portion of the poor lacks access to it.

Second, while studies of the political economy of development and the determinants of public goods provision usually conceptualize schools as one of many publicly provided "goods" or "services" that increase individual well-being, the qualitative evidence presented in the online annotations of this article suggests that the provision of primary schooling has sometimes been divorced from concerns about citizens' well-being. 
Further, the poor correlation between years of schooling and skills acquisition that this study documents indicates that years of schooling and enrollment rates are problematic measures of a "good" or "service" that benefits individuals. Measures of educational quality or the economic returns to schooling would represent a considerable improvement if the goal is to explain variation in the degree to which governments provide things that citizens value or benefit from. Future research could also complement this study by examining whether democratization improves educational quality.

Third, proponents of modernization theory often argue that education empowers citizens to demand democracy (Lipset 1960)-and perhaps because of the influence of this theory, past studies assumed that access to primary schooling before democratization was low. This study shows that modernization theory's testable implication that autocrats will refrain from providing mass education (Bourguignon and Verdier 2000) rarely holds. An interesting question stemming from this article is whether and when the provision of mass education under non-democracy, even in those cases when it sought mostly to indoctrinate the masses, backfired. Acemoglu et al. (2005) find that the timing of democratization is not endogenous to the expansion of education that precedes it. Friedman et al. (2016) find experimental evidence that increasing girls' schooling in Kenya increased women's empowerment inside the household but also increased their acceptance of the political status quo. Examining the conditions under which the provision of education helps cement or undermine non-democratic regimes would be a fruitful area for future research.

Despite the findings presented, democracies may still promote more human development than autocracies. If we agree with Sen (1999) that human development entails the ability to freely determine how we want to live our lives and that this requires certain political and civil rights that can only be present under democratic regimes, then almost by definition democracy will be preferable to non-democratic regimes in promoting human development-even when it does not lead to more access to primary schooling.

The most important puzzle that emerges from this study concerns the high levels of primary education provision observed under non-democracies. Recent subnational studies find evidence of elite-driven primary education expansion in specific countries (e.g., Andersson and Berger [2019] in Sweden; Gao [2018] in China). This article documents a general worldwide pattern of high access to primary schooling before democratization. Existing theories of autocratic regimes or the comparative politics of education literature have devoted insufficient attention to understanding what explains this pattern. Some recent studies suggest that external threats to territorial integrity (Darden and Mylonas 2015), the presence of mass domestic conflict and political instability (Paglayan 2017), and autocratic rulers' left-wing ideologies, including communism (Manzano 2017), all catalyzed non-democratic elites' incentives to provide mass education. The findings presented here underscore that expanding this line of inquiry is crucial for understanding what led to the global expansion of primary schooling. The rise and spread of primary education systems took place mostly under non-democratic regimes.

\section{SUPPLEMENTARY MATERIALS}

To view supplementary material for this article, please visit http://dx.doi.org/10.1017/S0003055420000647.

\section{DATA AVAILABILITY STATEMENT}

For quantitative analysis, replication materials can be found on Dataverse at https://oi.org/10.7910/DVN/ X2VJJX. This paper also uses Annotation for Transparent Inquiry (ATI), an approach to openness in qualitative scholarship. Access to the annotations, as an overlay to the digital article, can be found by viewing the full-text HTML of this article online. Access to a stand-alone copy of the annotations and underlying data is available here: https://doi.org/10.5064/ F6EOZGLB.

\section{REFERENCES}

Acemoglu, Daron, Simon Johnson, James A. Robinson, and Pierre Yared. 2005. "From Education to Democracy?" American Economic Review 95 (2): 44-9.

Acemoglu, Daron, and James A. Robinson. 2006a. Economic Origins of Dictatorship and Democracy. Cambridge: Cambridge University Press.

Acemoglu, Daron, and James A. Robinson. 2006b. "Economic Backwardness in Political Perspective." American Political Science Review 100 (1): 115-31.

Aghion, Philippe, Xavier Jaravel, Torsten Persson, and Dorothee Rouzet. 2019. "Education and Military Rivalry." Journal of the European Economic Association 17 (2): 376-412.

Albertus, Michael. 2015. Autocracy and Redistribution: The Politics of Land Reform. New York: Cambridge University Press.

Albertus, Michael, and Victor Menaldo. 2014. "Gaming Democracy: Elite Dominance during Transition and the Prospects for Eedistribution.” British Journal of Political Science 44 (3): 575-603.

Alesina, Alberto, and Byony Reich. 2013. "Nation-Building." NBER Working Paper No. 18839.

Alexander, Thomas. 1919. The Prussian Elementary Schools. New York: The Macmillan Company.

Almond, Gabriel A., and Sidney Verba. 1963. The Civic Culture: Political Attitudes and Democracy in Five Nations. Princeton, NJ: Princeton University Press.

Andersson, Jens, and Thor Berger. 2019. "Elites and the Expansion of Education in Nineteenth-Century Sweden." Economic History Review 72 (3): 897-924.

Angrist, Noam, Simeon Djankov, Pinelopi Goldberg, and Harry A. Patrinos. 2019. "Measuring Human Capital.” Working Paper. https://ssrn.com/abstract=3339416.

Ansell, Ben W. 2008. "Traders, Teachers, and Tyrants: Democracy, Globalization, and Public Investment in Education." International Organization 62 (2): 289-322.

Ansell, Ben W. 2010. From the Ballot to the Blackboard: The Redistributive Political Economy of Education. Cambridge: Cambridge University Press.

Ansell, Ben, and Johannes Lindvall. 2013. "The Political Origins of Primary Education Systems: Ideology, Institutions, and Interdenominational Conflict in an Age of Nation-Building." American Political Science Review 107 (3): 505-22. 
Ansell, Ben W., and David Samuels. 2014. Inequality and Democratization: an Elite-Competition Approach. New York: Cambridge University Press.

Avelino, George, David S. Brown, and Wendy Hunter. 2005. "The Effects of Capital Mobility, Trade Openness, and Democracy on Social Spending in Latin America, 1980-1999." American Journal of Political Science 49 (3): 625-41.

Barkin, Kenneth. 1983. "Social Control and the Volksschule in Vormärz Prussia." Central European History 16 (1): 31-52.

Barro, Robert, and Jong-Wha Lee. 2013. "A New Data Set of Educational Attainment in the World, 1950-2010." Journal of Development Economics 104: 184-98.

Benavot, Aaron, and Phyllis Riddle. 1988. "The Expansion of Primary Education, 1870-1940: Trends and Issues." Sociology of Education 61 (3): 191-210.

Boix, Carles. 2003. Democracy and Redistribution. Cambridge: Cambridge University Press.

Boix, Carles, Michael Miller, and Sebastian Rosato. 2012. "A Complete Data Set of Political Regimes, 1800-2007." Comparative Political Studies 46 (12): 1523-54.

Boli, John, Francisco O. Ramirez, and John W. Meyer. 1985. "Explaining the Origins and Expansion of Mass Education." Comparative Education Review 29 (2): 145-70.

Bonal, Xavier. 2016. "Education, Poverty, and the 'Missing Link': The Limits of Human Capital." In The Handbook of Global Education Policy, eds. Karen E. Mundy, Andy Green, Bob Lingard, and Antoni Verger, 97-110. Chichester, UK: John Wiley \& Sons.

Bourguignon, François, and Thierry Verdier. 2000. "Oligarchy, Democracy, Inequality and Growth." Journal of Development Economics 62 (2): 285-313.

Brambor, Thomas, Johannes Lindvall, and Annika Stjernquist. 2017. “The Ideology of Heads of Government, 1870-2012." Version 1.5. Department of Political Science, Lund University.

Brockliss, Laurence W. B., and Nicola Sheldon. 2012. Mass Education and the Limits of State Building, c. 1870-1930. Houndmills, UK: Palgrave Macmillan.

Brown, David S. 1999. "Reading, Writing and Regime Type: Democracy's Impact on Primary School Enrollment." Political Research Quarterly 52 (4): 681-707.

Brown, David S., and Wendy Hunter. 1999. "Democracy and Social Spending in Latin America, 1980-92." American Political Science Review 93 (4): 779-90.

Brown, David S., and Wendy Hunter. 2004. "Democracy and Human Capital Formation: Education Spending in Latin America, 1980 to 1997." Comparative Political Studies 37 (7): 842-64.

Brownson, Orestes Augustus. 1839. The Boston Quarterly Review 1838-1842. Boston: Benjamin H. Greene.

Budde, Gunilla. 2012. "From the 'Zwergschule' (One-Room Schoolhouse) to the Comprehensive School: German Elementary Schools in Imperial Germany and the Weimar Republic, 1870-1930." In Mass Education and the Limits of State Building, c. 1870-1930, eds. Laurence W. B. Brockliss and Nicola Sheldon, 95-116. Houndmills, UK: Palgrave Macmillan.

Bursztyn, Leonardo. 2016. "Poverty and the Political Economy of Public Education Spending: Evidence from Brazil." Journal of the European Economic Association 14 (5): 1101-28.

Busemeyer, Marius R., and Christine Trampusch. 2011.

"Comparative Political Science and the Study of Education." British Journal of Political Science 41 (2): 413-43.

Cantoni, Davide, Yuyu Chen, David Y. Yang, Noam Yuchtman, and Y. Jane Zhang. 2017. "Curriculum and Ideology." Journal of Political Economy 125 (2): 338-92.

Darden, Keith, and Anna Grzymala-Busse. 2006. "The Great Divide: Literacy, Nationalism, and the Communist Collapse." World Politics 59 (1): 83-115.

Darden, Keith, and Harris Mylonas. 2015. "Threats to Territorial Integrity, National Mass Schooling, Linguistic Commonality." Comparative Political Studies 49 (11): 1446-79.

Egaña Baraona, Maria Loreto. 2000. La Educacion Primaria Popular en el Siglo XIX en Chile: Una Practica de Politica Estatal. Santiago: Ediciones de la Direccion de Bibliotecas, Archivos y Museos.

Elliott, David. 1982. "Training Revolutionary Successors in Vietnam and China, 1958-1976: The Role of Education, Science and
Technology in Development." Studies in Comparative Communism 15 (1-2): 34-70.

Flora, Peter. 1983. State, Economy, and Society in Western Europe 1815-1975. A Data Handbook, Volume I: The Growth of Mass Democracies and Welfare States. Chicago: St. James Press.

Friedman, Willa, Michael Kremer, Edward Miguel, and Rebecca Thornton. 2016. "Education as Liberation?" Economica 83: $1-30$.

Gao, Pei. 2018. "Local Elites and Public Good Provision: Evidence from the Rise of Public Education in the Early 20th Century China". Working Paper. https://papers.ssrn.com/sol3/papers.cfm? abstract_id=3260504.

Gellner, Ernest. 1983. Nations and Nationalism. Ithaca, NY: Cornell University Press.

Gift, Thomas, and Erik Wibbels. 2014. "Reading, Writing, and the Regrettable Status of Education Research in Comparative Politics." Annual Review of Political Science 17: 291-312.

Gilens, Martin, and Benjamin I. Page. 2014. "Testing Theories of American Politics: Elites, Interest Groups, and Average Citizens." Perspectives on Politics 12 (3):564-81.

Grant, Nigel. 1964. Soviet Education. Middlesex, UK: Penguin Books.

Green, Andy. 1990. Education and State Formation: The Rise of Education Systems in England, France, and the USA. New York: St. Martin's Press.

Guevara, Jennifer, Agustina Paglayan, and Camila Perez-Navarro. 2018. "Historical Political Economy of Skills Formation: Evidence from 100 Years of Curriculum Policy Choices in Argentina and Chile." Paper presented at the American Political Science Association 2017 Annual Meeting. https://e50c00f1-c826-48c4-98cebef51415dedc.filesusr.com/ugd/a763a0_38c2b5cbf36845a7ac00e4 6087a650cb.pdf.

Guizot, François. 1860. Mémoires pour Servir à l'Histoire de Mon Temps, t.3. Paris: Michel Lévy Frères. https://babel.hathitrust.org/ cgi/pt?id=hvd.32044105321608\&view=1up\&seq=9.

Hanushek, Eric, and Ludger Woessmann. 2015. The Knowledge Capital of Nations: Education and the Economics of Growth. Cambridge, MA: MIT Press.

Harding, Robin, and David Stasavage. 2014. "What Democracy Does (and Doesn't Do) for Basic Services: School Fees, School Inputs, and African Elections." The Journal of Politics 76 (1): 229-45.

Hoffman, Philip T. 2015. "What Do States Do? Politics and Economic History." Journal of Economic History 75 (2): 303-32.

Jensen, Robert. 2010. "The (Perceived) Returns to Education and the Demand for Schooling." The Quarterly Journal of Economics 125 (2): 515-48.

Kaufman, Robert R., and Alex Segura-Ubiergo. 2001. "Globalization, Domestic Politics, and Social Spending in Latin America: A Time-Series Cross-Section Analysis, 1973-97." World Politics 53 (4): 553-87.

Kosack, Stephen. 2013. "The Logic of Pro-Poor Policymaking: Political Entrepreneurship and Mass Education." British Journal of Political Science 44: 409-44.

Kramon, Eric, and Daniel N. Posner. 2016. "Ethnic Favoritism in Education in Kenya." Quarterly Journal of Political Science 11 (1): 1-58.

Lake, David A., and Matthew A. Baum. 2001. "The Invisible Hand of Democracy: Political Control and the Provision of Public Services." Comparative Political Studies 34 (6): 587-621.

Lee, Jong-Wha, and Hanol Lee. 2016. "Human Capital in the Long Run." Journal of Development Economics 122: 147-69.

Lindert, Peter H. 2002. "Voice and Growth: Was Churchill Right?" Journal of Economic History 63 (2): 315-50.

Lindert, Peter H. 2004. Growing Public: Social Spending and Economic Growth since the Eighteenth Century. Cambridge: Cambridge University Press.

Lipset, Seymour M. 1960. Political Man: The Social Bases of Politics. New York: Doubleday.

Lott, John R., Jr. 1999. "Public Schooling, Indoctrination, and Totalitarianism." Journal of Political Economy 107 (6): 127-57.

Manzano, Dulce. 2017. Bringing Down the Educational Wall: Political Regimes, Ideology and the Expansion of Education. Cambridge: Cambridge University Press.

Mares, Isabela, and Didac Queralt. 2015. "The Non-Democratic Origins of Income Taxation." Comparative Political Studies 48 (14): 1974-2009. 
Mariscal, Elisa, and Kenneth Sokoloff. 2000. "Schooling, Suffrage, and the Persistence of Inequality in the Americas, 1800-1945." In Political Institutions and Economic Growth in Latin America: Essays in Policy, History, and Political Economy, ed. Stephen Haber, 159-218. Stanford, CA: Hoover Institution Press.

Melton, James Van Horn. 1988. Absolutism and the EighteenthCentury Origins of Compulsory Schooling in Prussia and Austria. Cambridge: Cambridge University Press.

Meltzer, Allan H., and Scott F. Richard. 1981. "A Rational Theory of the Size of Government." Journal of Political Economy 89 (5): 914-27.

Miguel, Edward. 2004. "Tribe or Nation? Nation Building and Public Goods in Kenya versus Tanzania." World Politics 56 (3): 328-62.

Mitchell, Brian R. 2007. International Historical Statistics 1750-2005. Basingstoke: Palgrave Macmillan.

Montt, Manuel. 1859. "Discurso del Presidente de la Republica en la Apertura del Congreso Nacional de 1859." In Chile, Documentos Parlamentarios. Discursos de Apertura en las Sesiones del Congreso i Memorias Ministeriales Correspondientes al Segundo Quinquenio de la Administracion Montt, 5-13. Santiago de Chile: Imprenta del Ferrocarril.

Nguyen, Trang. 2008. "Information, Role Models and Perceived Returns to Education: Experimental Evidence from Madagascar." Working Paper. https://150f11b7-a-62cb3a1a-s-

sites.googlegroups.com/site/mavalfortwebpage/home/teaching/ development-microeconomics-m1/Nguyen2008.pdf?attachauth= ANoY7crr907oRU8UtsLqSu1j_28Kj7ZWH-yaW_ Gp3I71aYrVVIHHL8RB0wpa9Nk9c1jOLXDjbMniMcN1Ld2 NOZsap1B4vf7YXP017PYsAq3O496YfyvveZxSNusi1tCzJI9 UnSyYXm-KKDC4ArumXSaBYkAPzHghiT942Tt4Zu71 ResKz78HuVUMfOh6UoFreYc-7QMZexUL0sfUfygH6aiAolJsqLuAxEawr6Rwt9N-pfya6AY6PXoHkXNiU6LexjGhYQCq8KD3mSXvcgygmOtNwftkCeg\%3D\%3D\& attredirects $=0$.

Olson, Mancur. 1993. "Dictatorship, Democracy, and Development.” American Political Science Review 87 (3): 567-76.

OECD (Organisation for Economic Co-operation and Development). PISA 2012 Results. http://www.oecd.org/pisa/ keyfindings/pisa-2012-results.htm

Paglayan, Agustina S. 2017. "Civil War, State Consolidation, and the Spread of Mass Education." Paper presented at the American Political Science Association 2017 Annual Meeting. https:// convention2.allacademic.com/one/apsa/apsa17/index.php? cmd= Online+Program+Download+Document\&document_type = document\&key=online_program_view_paper_downloads\& document key=7ecc8e17809bb0ee6c0636a4d6a5352b\& filename=apsa17_proceeding_1248679.pdf\&PHPSESSID= d6qvvfes556vqfnrmqf95gvtm4.

Platas, Melina R. 2019. "Culture and the Persistence of Educational Inequality: Lessons from the Muslim-Christian Education Gap in Africa." Working Paper. Available at https://mplatas.files.wordpress. com/2018/05/persistence_may2018.pdf.
Przeworski, Adam et al. 2013. Political Institutions and Political Events (PIPE) Data Set. Department of Politics, New York University. https://sites.google.com/a/nyu.edu/adam-przeworski/ home/data.

Ramirez, Francisco O., and John Boli. 1987. "The Political Construction of Mass Schooling: European Origins and Worldwide Institutionalization." Sociology of Education 60 (1): 2-17.

Reisner, E. Hartman. 1922. Nationalism and Education since 1789: A Social and Political History of Modern Education. New York: The Macmillan Company.

Ross, Michael. 2006. "Is Democracy Good for the Poor?" American Journal of Political Science 50 (4): 860-74.

Sarmiento, Domingo F. (1845) 1964. Facundo; civilizacion y barbarie Buenos Aires: Espasa-Calpe.

Sarmiento, Domingo F. (1849) 2011. Educacion Popular. La Plata: UNIPE: Editorial Universitaria.

Scheve, Kenneth F., and David Stasavage. 2016. Taxing the Rich: A History of Fiscal Fairness in the United States and Europe. Princeton, NJ: Princeton University Press.

Sen, Amartya. 1999. Development as Freedom. New York: Knopf

Shadish, William R., Thomas D. Cook, and Donald T. Campbell. 2002. Experimental and Quasi-Experimental Designs for Generalized Causal Inference. Boston: Houghton Mifflin.

Squicciarini, Mara P., and Nico Voigtländer. 2015. "Human Capital and Industrialization: Evidence from the Age of Enlightenment." The Quarterly Journal of Economics 130 (4): 1825-83.

Squicciarini, Mara P., and Nico Voigtländer. 2016. "Knowledge Elites and Modernization: Evidence from Revolutionary France." NBER Working Paper No. 22779.

Stasavage, David. 2005. "Democracy and Education Spending in Africa." American Journal of Political Science 49 (2): 343-58.

Tedesco, Juan Carlos. 1986. Educacion y sociedad en la Argentina: (1880-1945). Buenos Aires: Ediciones Solar.

Testa, Patrick A. 2018. "Education and Propaganda: Tradeoffs to Public Education Provision in Nondemocracies." Journal of Public Economics 160: 66-81.

United States Bureau of Education. 1870. Report of the Commissioner of Education made to the Secretary of the Interior for the year ... with accompanying papers, 41 vols. Washington, DC: U.S. Government Printing Office.

United States Department of Health, Education, and Welfare. Office of Education. 1959. Soviet Commitment to Education: Report of the First Official U.S. Education Mission to the USSR. Washington, DC: U.S. Government Printing Office.

United States Department of Health, Education, and Welfare. Office of Education. 1960. Soviet Education Programs. Washington, DC: U.S. Government Printing Office.

Weber, Eugen. 1976. Peasants into Frenchmen: The Modernization of Rural France, 1870-1914. Stanford, CA: Stanford University Press.

World Bank. EdStats. https://datatopics.worldbank.org/education/.

World Bank. 2018. World Development Report 2018: Learning to Realize Education's Promise. Washington, DC: The World Bank. 